\title{
GABA-mediated Positive Autofeedback Loop Controls Horizontal Cell Kinetics in Tiger Salamander Retina
}

\author{
Maarten Kamermans ${ }^{a}$ and Frank Werblin \\ Department of Molecular and Cell Biology, Division of Neurobiology, University of California at Berkeley, Berkeley, \\ California 94720
}

Horizontal cells (HCs) appear to release, and also to be sensitive to, GABA. The external GABA concentration is increased with depolarization of the $\mathrm{HC}$ membrane via an electrogenic GABA transporter. This extracellular GABA opens a GABA $A_{A}$-gated $\mathrm{Cl}^{-}$channel in the HC membrane. Since the equilibrium potential for $\mathrm{Cl}^{-}\left(E_{\mathrm{cI}}\right)$ is near $-20 \mathrm{mV}$, GABA released by the HC further depolarizes the HC. The GABA transporter and the GABA receptor thus constitute a positive feedback loop in the HC membrane. This loop can slow down the kinetics of the light responses in HCs.

GABA released via the GABA transporter can affect the GABA $_{A}$ receptor, probably because diffusion from the extracellular space is normally restricted by the intact retinal structure. We therefore used retinal slices rather than isolated HCs to maintain that structure. To measure single-cell currents in the slice, HCs were electrically uncoupled by including CAMP in the patch pipette. Under these conditions, bath application of GABA elicited two currents: (1) a picrotoxin-blocked current reversing near $E_{c 1}$, probably mediated by $\mathrm{GABA}_{A}$ receptors, and (2) a picrotoxin-insensitive current similar to that elicited by cis-4-hydroxynipecotic acid (NIP) shown in other preparations to act at the GABA transporter.

Under physiological conditions, the $\mathrm{HC}$ membrane potential is controlled by two major conductances, the GABA $_{\mathrm{A}}$ gated $\mathrm{Cl}^{-}$conductance described above, and the glutamategated conductance modulated by photoreceptor input. $A$ bright light flash eliminates the glutamate-gated conductance, leaving only the GABA-gated $\mathrm{Cl}^{-}$conductance to control the membrane. With the $\mathrm{Cl}^{-}$conductance a significant fraction of the overall membrane conductance the GABAergic positive feedback loop can decrease the response kinetics.

We increased the ambient extracellular GABA concentration by adding $50 \mu \mathrm{M}$ GABA to the extracellular medium. This increased the ambient $\mathrm{Cl}^{-}$conductance, but the transporter still modulated $\mathrm{Cl}^{-}$conductance because responses to light stimuli were significantly slowed. The slowdown of the HC response could be reversed by interrupting the loop in two

\footnotetext{
Received June 24, 1991; revised Jan. 15, 1992; accepted Jan. 17, 1992.

This work was supported by NIH Grant EY00561. M.K. is a fellow of the Netherlands Organization for Scientific Research

Correspondence should be addressed to Frank Werblin, Department of Molecular and Cell Biology, Division of Neurobiology, 145 LSA, University of California at Berkeley, Berkeley, CA 94720.

a Present address: Laboratory of Medical Physics, University of Amsterdam, Meibergdreef 15,1105 AZ Amsterdam-Zuidoost, The Netherlands.

Copyright (C) 1992 Society for Neuroscience $0270-6474 / 92 / 122451-13 \$ 05.00 / 0$
}

ways: (1) picrotoxin opened the loop and speeded the responses by uncoupling the GABA concentration from control of the membrane conductance, and (2) NIP opened the loop by uncoupling the extracellular GABA concentration from the $\mathrm{Cl}^{-}$conductance and therefore the membrane potential.

The loop could also be inhibited in two ways that involved only the recorded celt: (1) changing $E_{\mathrm{cl}}$ from $-20 \mathrm{mV}$ to -50 $\mathrm{mV}$ by lowering the $\mathrm{Cl}^{-}$concentration in the pipette reversed the sign of the loop in the recorded cell, and (2) voltage clamping the $\mathrm{HC}$ membrane uncoupled the GABA transporter from GABA-elicited control by the membrane potential in the recorded cell.

Together, these results suggest that response kinetics of HCs are controlled by the GABAergic positive feedback loop, and that the loop exists in individual HCs. This may be the first example of positive feedback in a neuron that slows down its response.

Horizontal cells (HC) form an extensive electrically coupled network in the outer retina. In salamander, HCs receive input from both rods and cones and feed back antagonistically to the cones. Because of coupling, the space constant for the HC network is extended, so the network mediates a surround response in cones and all subsequent retinal cell types including $\mathrm{HCs}$ themselves (Kaneko, 1971; Marshall and Werblin, 1978; Thibos and Werblin, 1978a,b; Attwell et al., 1983; Kamermans et al., 1989a,b; Hare and Owen, 1990).

In amphibia, the receptive field size of HCs increase during dark adaptation (Dong and McReynolds, 1991) and the response kinetics slow down dramatically (Stone and Witkovsky, 1984; $\mathrm{Wu}, 1987$; Belgum and Copenhagen, 1988; Yang and $\mathrm{Wu}$, $1989 \mathrm{a}, \mathrm{b})$. The reduction of the receptive field size can be explained by an increase of membrane conductance or a decrease of the gap-junction conductance or both. Dopamine may be the neurotransmitter that mediates the changes in receptive field size since it induces both changes in membrane and gap-junction conductance (Lasater and Dowling, 1985; Mangel and Dowling, 1985; Knapp and Dowling, 1987). It is, however, not yet understood how the response kinetics are altered by dark adaptation. The kinetics of the cone and bipolar cell (BC) responses are relatively unaffected by adaptation, so the mechanism responsible for controlling $\mathrm{HC}$ kinetics must lie at the $\mathrm{HCs}$ themselves.

GABA appears to play a critical role in determining the $\mathrm{ki}$ netics of the HC light response (Stone and Witkovsky, 1984; $\mathrm{Wu}, 1987$; Yang and $\mathrm{Wu}, 1989 \mathrm{a}, \mathrm{b})$. In fish and amphibians, GABA is released in a $\mathrm{Ca}^{2+}$-independent way, probably via a 
G $\Lambda \mathrm{B} \Lambda$ transporter (Schwartz, 1982; Yazulla and Kleinschmidt, 1983; Ayoub and Lam, 1984; Schwartz, 1987). We show here that a similar mechanism appears to operate in tiger salamander HCs.

Further, a $\mathrm{GABA}_{\mathrm{A}}$-gated $\mathrm{Cl}^{-}$conductance appears to exist in these $\mathrm{HCs}$. It has been reported that the $\mathrm{Cl}^{-}$equilibrium potential $\left(E_{\mathrm{Cl}}\right)$ in $\mathrm{HCs}$ is usually near $-20 \mathrm{mV}$ (Miller and Dacheux, 1983; Djamgoz and Laming, 1987). With $E_{\mathrm{Cl}}$ near $-20 \mathrm{mV}$, the GABA transporter and the $\mathrm{GABA}_{\mathrm{A}}$-gated $\mathrm{Cl}^{-}$conductance could constitute a positive feedback loop in the $\mathrm{HC}$ membrane that affects response kinetics. Indeed, Yang and Wu (1989b) have shown in salamander that the slowdown of the HC light response kinetics, normally occurring during dark adaptation, can be elicited in the light-adapted retina by application of GABA.

The GABAergic positive feedback loop has previously been suggested by Kamermans (1989; Kamermans et al., 1990, 1991), Gilbertson et al. (1990), and Stockton and Slaughter (1991), but no direct evidence showing the existence of the loop has been available. In this article, we show the presence of both major components of the loop and show how the loop affects the $\mathrm{HC}$ light responses kinetics by opening the loop in a variety of ways.

An abstract of this work has been presented previously (Kamermans and Werblin, 1991).

\section{Materials and Methods}

Preparation. Whole-cell patch recordings (Hamill et al., 1981) were made from horizontal cells in a retinal slice from larval tiger salamanders (Ambystoma tigrinum). The slices were prepared using the procedure described by Werblin (1978). In short, small pieces of retina were placed with the vitreous side down on a Millipore (Bedford, MA) filter. After the retina had attached to the filtcr, the sclera and the pigment epithelium were removed and the retina was bathed in Ringer's solution. The filter and the retina were sliced with a razor blade in $200-\mu \mathrm{m}$-thick slices. The filter strips with the attached retinal slice were mounted with Vaseline such that the sliced surface could be viewed under a Zeiss $40 \times$ water-immersion objective. The entire slice procedure was done under dim red light illumination. No attempt was made to dark adapt the retinal slices completely, but the preparation was left in the dark for at least $30 \mathrm{~min}$ prior to the first experiment.

Cell identification. Cells in the slice were visualized using Hoffmann modulation contrast optics (Modulation Optics, Inc., Greenvale, NY) under infrared illumination with the aid of a video camera (Sony CCD $\mathrm{XC}-57$ ). Horizontal cells were identified by filling them with lucifer yellow (Molecular Probes Inc., Eugene, OR).

Recording system. Patch electrodes of 5-10 M $\Omega$ resistance when mcasured in Ringer's solution were pulled on a Sutter P30 or on a Sutter PC87 (Sutter Inc., Novato, CA) puller using borosilicate glass (TW 150F4, World Precision Instruments Inc., New Haven, CT). The electrode series resistance during a whole-cell recording was 10-25 M $\Omega$. A List L/M-EPC7 patch clamp (Medical Systems Corp., Greenvale, NY) was used to voltage or current clamp HCs. Filtering was at $3 \mathrm{kHz}$. The response was sampled at a rate of 0.5 or $5.0 \mathrm{kHz}$ by a DATA Translation DT2801A interface and recorded at an IBM AT. Throughout this article, the sustained currents are plotted.

Bathing solutions. The Ringer's solution contained $108 \mathrm{~mm} \mathrm{NaCl}, 2.5$ $\mathrm{mm} \mathrm{KCl}, 1 \mathrm{~mm} \mathrm{MgCl}, 1 \mathrm{~mm} \mathrm{CaCl}_{2}, 5 \mathrm{~mm}$ HEPES, and $3 \mathrm{~mm}$ glucose. In all experiments, $250 \mu \mathrm{M} 8-\mathrm{Br}$-cAMP was used to uncouple the HCs. The $\mathrm{pH}$ was kept at 7.8. The concentrations of GABA, picrotoxin (PTX), 6-cyano-7-nitroquinoxaline-2,3-dione (CNQX) (Research Biochemicals Inc., Natick, MA), and cis-4-hydroxynipecotic acid (NIP) (Research Biochemicals) are given in the Results. All chemicals were obtained from Sigma (St. Louis, MO), unless otherwise stated. Hepes was obtained from CalBiochem (La Jolla, CA).

Electrode solutions. The electrode solution contained $116 \mathrm{~mm} \mathrm{K-glu-}$ conate $+\mathrm{KCl}, 1 \mathrm{~mm} \mathrm{MgCl}, 0.1 \mathrm{~mm} \mathrm{CaCl}_{2}, 4 \mathrm{~mm}$ HEPES, $1 \mathrm{~mm}$ EGTA, $1 \mathrm{mM} \mathrm{Na}$-ATP, and $0.1 \mathrm{mM} \mathrm{Na}_{2}$-GTP. In all experiments, $1 \mathrm{mM}$ cAMP was present in the pipette to uncouple the HCs (Miyachi and Murakami, 1989). $E_{\mathrm{Cl}}$ was set by changing the ration of $\mathrm{K}$-gluconate and $\mathrm{KCl}$ in the electrode solution.
Liquid junction potential correction. The liquid junction potentials were measured by placing the electrode in the electrode solution, then changing to the Ringer's solution. The difference in offset is the liquid junction potential. All membranc potential values in this article arc corrected for these junction potentials.

Light stimulation. All light stimuli were full-field white light stimuli. The intensity was circa 50 lux.

\section{Results}

Rationale for these experiments: site and action of the GABAergic positive feedback loop

Earlier studies in fish and amphibian retina have demonstrated the existence of a GABA transporter in HCs (Schwartz, 1982, 1987; Yazulla and Kleinschmidt, 1983; Ayoub and Lam, 1984). This transporter has characteristics similar to the high-affinity GABA-uptake carrier in other preparations. In a simple vicw of this GABA transporter, the electrochemical gradients of $\mathrm{Na}^{+}$ and $\mathrm{Cl}^{-}$are coupled to the electrochemical gradient of GABA (Kanner and Schuldiner, 1987; Keynan and Kanner, 1988). The transporter redistributes $\mathrm{GABA}, \mathrm{Na}^{+}$, and $\mathrm{Cl}^{-}$with changes in potential to reestablish an equilibrium determined by the stoichiometry of the transporter and the membrane potential. Upon depolarization, the gradients for $\mathrm{Na}^{+}$and $\mathrm{Cl}$ will be reduced leading to release of $\mathrm{GABA}, \mathrm{Na}^{+}$, and $\mathrm{Cl}^{-}$until all electrochemical gradients are once again at equilibrium.

The resulting increase of the extracellular GABA acts at the $\mathrm{GABA}_{\mathrm{A}}$ receptors in the $\mathrm{HC}$ membrane to increase the $\mathrm{Cl}^{-}$ conductance. With $E_{\mathrm{Cl}}$ near $-20 \mathrm{mV}$, this will normally generate an inward current causing a membrane depolarization. The depolarization will lead to a subsequent increase in the GABA release via the transporter in a positive feedback loop (Fig. 1). The positive feedback loop will also opcratc during membrane hyperpolarization, and as we show below, it will slow the $\mathrm{HC}$ light response.

We show here that the $\mathrm{GABA}_{\mathrm{A}}$-gated $\mathrm{Cl}^{-}$conductance competes with the glutamate-elicited conductance for control of the $\mathrm{HC}$ membrane potential. These two conductances are of similar orders of magnitude, but their relative contribution depends upon the state of the $\mathrm{HC}$. For example, the relative $\mathrm{GABA}_{\mathrm{A}}$ elicited $\mathrm{Cl}^{-}$conductance is greatest in the dark-adapted state just following a light flash when the glutamate-elicited conductance is rapidly reduced. It is under these conditions that the slowdown of the response by the GABAergic positive feedback loop is most evident.

The functional integrity of the GABAergic positive feedback loop requires that released $\mathrm{GABA}$ has direct access to the $\mathrm{GA}$ $\mathrm{BA}_{\mathrm{A}}$ receptors. So, the GABA released by the transporter is probably kept from diffusing rapidly from the $\mathrm{GABA}_{\mathrm{A}}$ receptor by a retinal structure of limited extracellular space. That structure would be lost in dissociated HCs. We therefore used retinal slices throughout these experiments to maintain this structure. To minimize the network interactions, electrical coupling between HCs was reduced with cAMP (Miyachi and Murakami, 1989) and the glutamate-mediated photoreceptors input was blocked with CNQX (Yang and Wu, 1989c).

\section{Responses of HCs in GABA Ringer's solution are slower than those of photoreceptors and BCs}

Yang and Wu (1989b) showed that application of GABA to a light-adapted retina resulted in slow $\mathrm{HC}$ responses similar to those seen in the dark-adapted retina. Therefore, we used 50 $\mu \mathrm{M}$ GABA to simulate dark adaptation in $\mathrm{HCs}$ in the retinal slice. Clearly, this does not set the absolute concentration of 


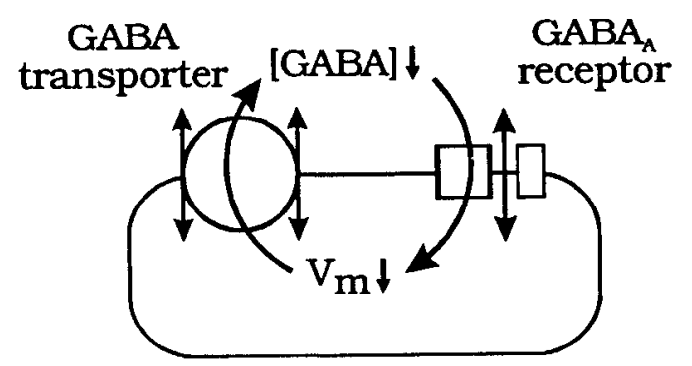

Figure 1. The proposed GABAergic positive feedback loop. The loop consists of two major components; the GABA transporter and the GA$\mathrm{BA}_{\mathrm{A}}$ receptor. The GABA transporter couples the membrane potential $\left(V_{m}\right)$ to the extracellular GABA concentration ([GABA/). The GABA receptor couples extracellular GABA concentration to the membrane potential. Since the $\mathrm{Cl}$ equilibrium potential is more positive than the resting membrane potential, reduction of the extracellular GABA concentration results in hyperpolarization and thus in further reduction of the extracellular GABA concentration and further hyperpolarization.

GABA or any other transmitter at the receptors because we routinely measure synaptic transmission in retinal slices bathed in normal Ringer's lacking amino acids.

Figure 2 shows cone, $\mathrm{HC}$, and $\mathrm{BC}$ responses to full-field light stimuli with and without GABA in the Ringer's solution. Cone and $\mathrm{BC}$ responses are almost unaffected by GABA, but $\mathrm{HC}$ ONset responses slow down dramatically. In the GABA Ringer's solution, the ONset phase of the $\mathrm{HC}$ response shows a characteristic inflection, suggestive of a regenerative mechanism (Fig. 2, arrow). The HC response shape in the GABA Ringer's solution is similar to that reported for HC's in an isolated retina (Yang and $\mathrm{Wu}, 1989 \mathrm{~b}$ ). This shows that the $\mathrm{HC}$ response in the slice preparation is physiological and that the choice of $E_{\mathrm{Cl}}(-17.3$ $\mathrm{mV}$ ) was close to the physiological value. Miller and Dacheux (1983) reported $E_{\mathrm{Cl}}$ of $-17.3 \mathrm{mV}$ in mudpuppy $\mathrm{HCs}$, whereas Djamgoz and Laming (1987) reported $E_{\mathrm{Cl}}$ of $-19 \mathrm{mV}$ in fish $\mathrm{HCs}$. In the experiments where we recorded cone and $\mathrm{BC}$ responses, $E_{\mathrm{C}}$ was set at $-49.2 \mathrm{mV}$, which is close to the presumed values of $E_{\mathrm{C}}$ in these cells.

Since HCs feed back to cones, some changes in the sustained part of the cone and $\mathrm{BC}$ responses might be expected with application of $50 \mu \mathrm{M}$ GABA. No dramatic changes were found. The change in the response shape may have been diminished because we used slices. In slices, feedback from the HCs via the cones to the BCs may have been limited (but see Attwell et al., 1983).

\section{Similar $/ / V$ relation of HCs in isolated cells and in the slice preparation}

Figure 3 shows the current responses to voltage steps of a dissociated voltage-clamped $\mathrm{HC}(a)$ and a pharmacologically isolated $\mathrm{HC}$ in the slice with $25 \mu_{\mathrm{M}} \mathrm{CNQX}$ in the bath $(b)$. The holding potential was $-70 \mathrm{mV}$, and the potential was stepped to different potentials in increments of $10 \mathrm{mV}$. Figure 3 shows that HCs in the slice have characteristics similar to those of dissociated HCs. HCs in both preparations have a slowly activating outward rectifier, a small fast-inactivating inward current, and finally a slowly activating inward rectifier as reported for isolated fish HCs (Lasater, 1986). No attempt was made in this study to evaluate the various components of the current in detail.

The input resistance at $-45 \mathrm{mV}$ of the dissociated $\mathrm{HC}$ was $2.7 \mathrm{G} \Omega$ and of the $\mathrm{HC}$ in the slice was $1.2 \mathrm{G} \Omega$. The mean input

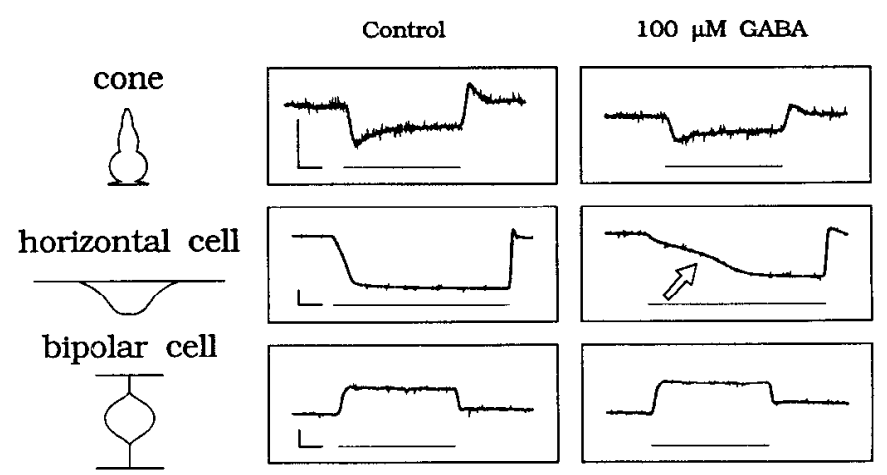

Figure 2, Light response of a cone, an $\overline{\mathrm{HC}}$, and a depolarizing $\mathrm{BC}$ in a Ringer's solution without and with GABA. $\bar{H} C$ responses in a GABA Ringer's solution show the characteristic regenerative shape (arrow), whereas the responses of the cone and $\mathrm{BC}$ are hardly affected by GABA. $E_{\mathrm{Cl}}$ was set in the $\mathrm{HC}$ at $-17.3 \mathrm{mV}$, and in the cone and $\mathrm{BC}$, at -49.2 $\mathrm{mV}$. Calibration: $10 \mathrm{mV}, 300 \mathrm{msec}$.

resistance of HCs in the slice recorded under these conditions was $0.5 \pm 0.3 \mathrm{G} \Omega(n=38)$. For comparison, the mean input resistance of cultured catfish $\mathrm{HCs}$ of which all voltage-gated currents were blocked by TTX, $\mathrm{Cs}^{+}, \mathrm{Co}^{+}$, and tetraethylammonium is $0.90 \pm 0.29 \mathrm{G} \Omega$ (DeVries and Schwartz, 1989).

The lower input resistance of the pharmacologically isolated HCs in the slice compared to the dissociated HCs may be due to the loss of the very long processes of the dissociated $\mathrm{HCs}$ during the dissociation process or may be due to some remaining

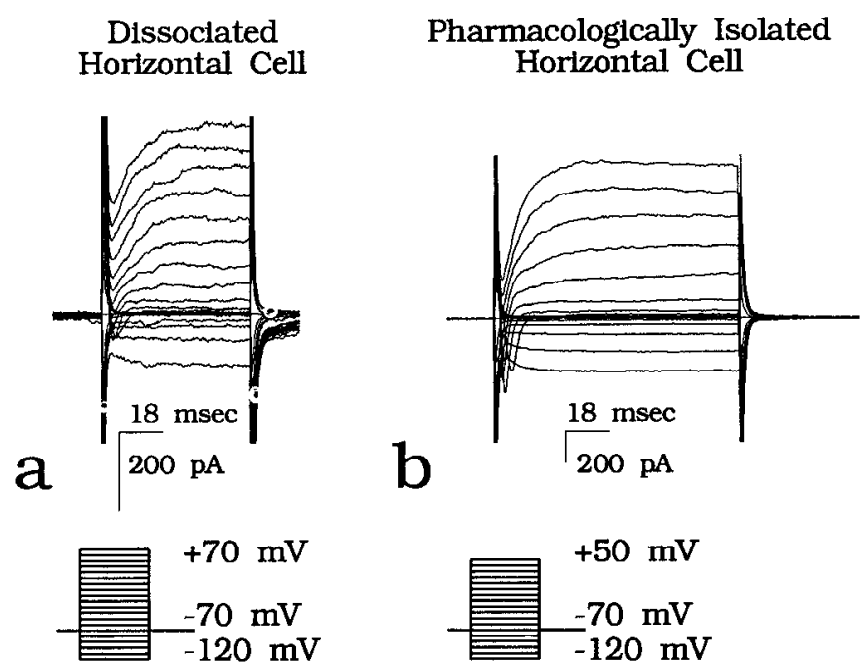

Figure 3. Comparison of the currents induced in dissociated and in pharmacologically isolated HCs. To prepare the dissociated $\mathrm{HCs}$, an isolated retina was incubated in a $\mathrm{Ca}^{2+}$-free Ringer's solution with 1 $\mathrm{mg} / \mathrm{ml}$ protease type VII (Sigma, St. Louis, MO) for $30-40 \mathrm{~min}$ at $27^{\circ} \mathrm{C}$. The retina was rinsed with a Ringer's solution containing $0.1 \%$ BSA (Sigma) of $5 \mathrm{~min}$ and then triturated with a fire-polished large-tip pipette $(0.5 \mathrm{~mm})$ in normal Ringer's solution. IICs where characterized on morphological criteria (many processes and no Landolt's club process) and on the absence of spikes. $a$, The current responses of a dissociated $\mathrm{HC}$. The holding potential was $-70 \mathrm{mV}$, and the $\mathrm{HC}$ membrane potential was stepped from the holding potential to -120 up to $+80 \mathrm{mV}$ in steps of $10 \mathrm{mV}$ for $60 \mathrm{msec} . b$, The current responses of a HC in a slice with $250 \mu \mathrm{M} 8$-Br-cAMP and $25 \mu \mathrm{M}$ CNQX in the bath solution and $1 \mathrm{mM}$ cAMP in the pipette. The holding potential was $-70 \mathrm{mV}$, and the cell was stepped from the holding potential to -120 up to +50 $\mathrm{mV}$ in steps of $10 \mathrm{mV}$ for $100 \mathrm{msec}$. In both cells $E_{\mathrm{Cl}}$ was set at -20.5 $\mathrm{mV}$. 


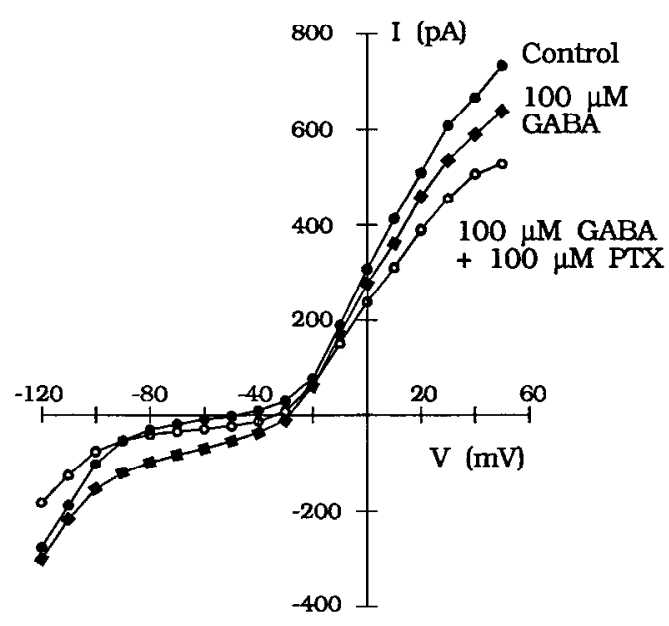

Figure 4. The sustained $I / V$ curves for the pharmacologically isolated HC from Figure 3 in the control Ringer's solution (solid circles) in a $100 \mu \mathrm{M}$ GABA Ringer's solution (squares), and in a $100 \mu \mathrm{M}$ GABA and $100 \mu \mathrm{M}$ PTX Ringer's solution (open circles).

electrical coupling of the pharmacologically isolated HCs in the slice since DeVrics and Schwartz (1989) reportcd that cAMP uncoupled HCs by $90 \%$. Although we cannot exclude that the HCs were still somewhat coupled, the HCs in the slice are essentially isolated.

\section{$\mathrm{GABA}_{\mathrm{A}}$ receptor and GABA transporter currents in HCs}

Figure 4 shows the effect of GABA and PTX on the $I / V$ relation of the pharmacologically isolated $\mathrm{HC}$ from Figure 3 . The solid circles show the control $I / V$ curve of the $\mathrm{HC}$. The squares show the $I / V$ curve when $100 \mu \mathrm{M}$ GABA is added to the Ringer's solution, and the open circles show the $I / V$ curve with $100 \mu \mathrm{M}$ GABA and $100 \mu \mathrm{M}$ PTX.

GABA induced two currents, one sensitive to PTX and one insensitive to PTX. Furthermore, Figure 4 shows that GABA does not significantly change the activation range of the various components of the $I / V$ relation. Therefore, the changes seen in the response dynamics duc to GABA application can not be attributed to changes in activation ranges in the voltage-gated currents. The properties of both components of the GABAinduced current will be evaluated below.

\section{$P T X$-sensitive GABA-induced current}

Figure 5 shows the GABA-induced currents for the HC of Figure 4. The difference between the squares and the solid circles in Figure 4 is the total GABA-induced current (Fig. $5 a$ ), and the difference between the squares and the open circles in Figure 4 is the PTX-sensitive GABA-induced current, most likely a GABA-gated $\mathrm{Cl}^{-}$current (Fig. $5 b$ ). The reversal potential of the GABA-gated $\mathrm{Cl}^{-}$current is around $-20 \mathrm{mV}$, which is close to $E_{\mathrm{Cl}}(-20.5 \mathrm{mV})$. The mean conductance of the population of the GABA-gated $\mathrm{Cl}^{-}$channels was $0.89 \pm 0.42 \mathrm{nS}(n=15)$. This is probably an underestimate of this conductance since we used cAMP to uncouple HCs and it has becn reported that the $\mathrm{Cl}^{-}$flux in rat brain synaptoneurosomes through the $\mathrm{GABA}_{\mathrm{A}^{-}}$ gated channels is reduced by forskolin and by cAMP (Heuschneider and Schwartz, 1989). For comparison, the endogenous glutamate conductance, which is the current that could be blocked with CNQX when no glutamate was added, was $0.98 \pm 0.69$ $\mathrm{nS}(n=19)$. This value is presumably an overestimate since, as

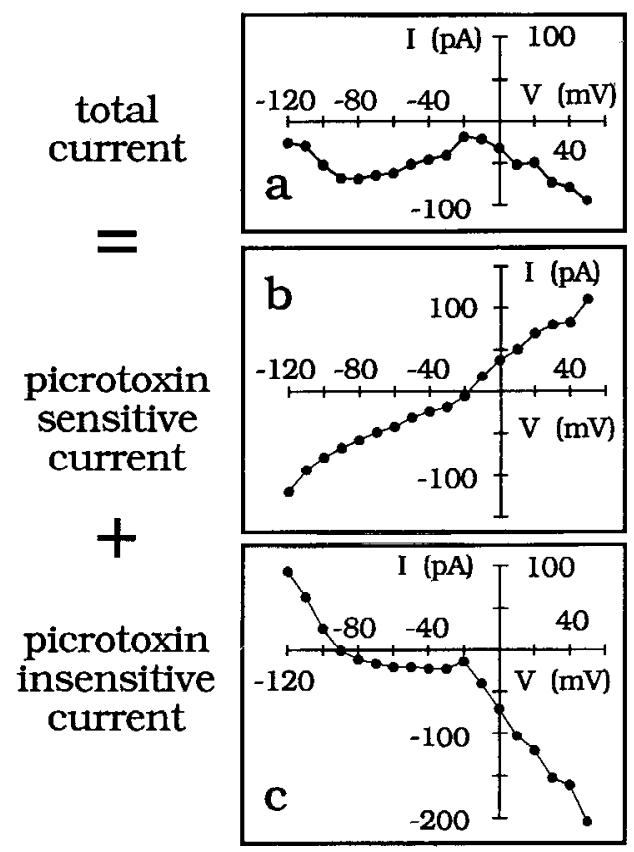

Figure 5. Two GABA-induced currents. $a$, The $I / V$ relation of total GABA-induced current in the $\mathrm{HC}$ from Figures 3 and 4 . This $I / V$ relation is the difference between the squares and the solid circles in Figure 4. This current consists of two parts, a PTX-sensitive and a PTXinsensitive current. $b$, The PTX-sensitive GABA-induced current in the same cell. This $I / V$ relation is the difference between the squares and the open circles in Figure 4. $c$, The PTX-insensitive GABA-induced current in the same cell. This $I / V$ relation is the difference between the open and the solid circles in Figure 4.

is shown by Knapp and Dowling (1987), 8-Br-cAMP enhances the sensitivity of the kainate-sensitive receptor and thus increases the conductance. The large SEs in these conductance values may be the result of the poor control we had over the adaptation state of the preparation.

Based on the above considerations, it is likely that the GABAgated $\mathrm{Cl}^{-}$conductance can, under certain conditions, become larger than the glutamate-gated conductance. This is necessary if the GABAergic positive autofeedback loop is to have a significant effect on the $\mathrm{HC}$ kinetics.

\section{$P T X$-insensitive GABA-induced current}

The remaining component of the GABA-induced current, the difference between the open circles and the solid circles in Figure 4 is most likely a transporter current, as will be shown below (Fig. $5 c$ ). It reversed near $-90 \mathrm{mV}$ and had a sharp knee around $-20 \mathrm{mV}$. The properties of the knee varied widely between the experiments, and the knee was sometimes completely absent. It is highly unlikely that this current is due to activation of a $\mathrm{GABA}_{\mathrm{B}}$ receptor on the HCs since that would be either a current carried by $\mathrm{Cl}^{-}$, a K ${ }^{+}$current, or modulation of a $\mathrm{Ca}^{2+}$ current. None of these conductances would give rise to the observed current.

NIP has bccn shown to inhibit GABA uptake via the highaffinity GABA uptake carrier (Johnston et al., 1976; KrogsgraadLarsen, 1980). This carrier may be similar to the GABA transporter in HCs. NIP has been shown to affect the GABA transporter in HCs in toad (Schwartz, 1987), in carp (Kamermans, 1989), and in skate (Malchow and Ripps, 1990). Figure $6 a$ shows the effect of NIP on the $I / V$ relation of a HC in the 


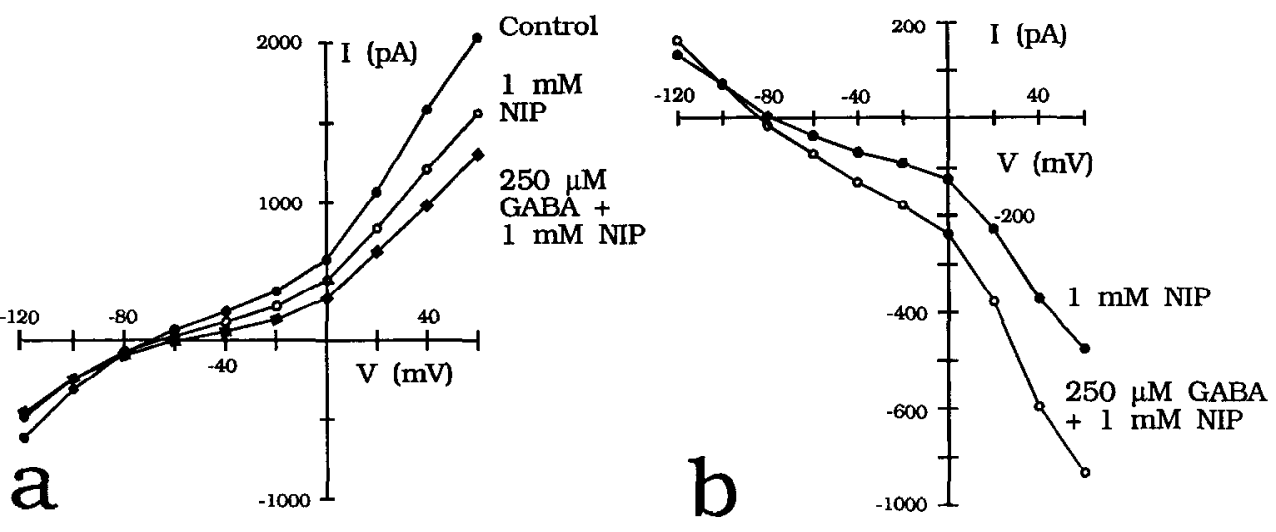

Figure 6. $a$, The effect of NIP and GABA on the sustained $I / V$ curves for a pharmacologically isolated $\mathrm{HC}$. Three $I / V$ relations are given. Solid circles, control; open circles, with $1 \mathrm{mM}$ NIP; squares, with $1 \mathrm{mM}$ NIP and $250 \mu \mathrm{M}$ GABA. $b$, NIP- and NIP+GABA-induced currents from $a$. The solid circles give the NIP-induced current, and the open circles give the NIP+GABA-induced current. $E_{\mathrm{C}}$ was set at $-20.5 \mathrm{mV}$. slice. At $100 \mu \mathrm{M}$ PTX and $25 \mu \mathrm{M}$ CNQX were added to the bath solution to block PTX-sensitive GABA and glutamate inputs to the HC. Figure $6 b$ shows the NIP-induced current: 1 mM NIP induces a current with characteristics similar to the PTX-insensitive GABA-induced current (Fig. 5c). Lower doses of NIP induced similar but smaller currents. Application of $250 \mu \mathrm{M}$ GABA to the 1 mM NIP Ringer's solution only increased the current but did not change its characteristics. In all experiments, the NIP- and PTX-insensitive GABA currents were roughly additive at all potentials, even at this high NIP concentration. This suggests that NIP is a competitive agonist for GABA at the GABA transporter. This conclusion seems contradictory to the notion that NIP is a potent GABA uptake inhibitor. However, NIP will inhibit GABA uptake acting, in this case, as a potent agonist. The finding that NIP is an agonist is consistent with the results of Malchow and Ripps (1990) in skate.

It has been reported that NIP also acts as a GABA $_{\mathrm{A}}$ agonist (Schwartz, 1987; Stockton and Slaughter, 1991). To test for this possibility, we substituted choline ${ }^{+}$for all $\mathrm{Na}^{+}$in the bath solution to block uptake via the transporter and recorded with patch-clamp electrodes from pharmacologically isolated HCs in the slice of salamander retina. In all five cells tested, NIP at concentrations as high as $1 \mathrm{mM}$ did not induce a current. The experiments show that NIP does not act as a GABA $\mathrm{A}_{\mathrm{A}}$ agonist in this preparation. This is in accordance with the findings of Krogsgraad-Larsen (1980), who showed that the GABA receptor is more than 3000 times less sensitive to NIP than to GABA. NIP at $1 \mathrm{~mm}$ would thus be equivalent to less than $0.3 \mu \mathrm{M}$ GABA, which is far below $40 \mu \mathrm{M}$, the $K_{m}$ value of the $\mathrm{GABA}_{\mathrm{A}}$ receptor in salamander HCs (Gilbertson et al., 1990).

The reasons for the different results in our experiments and those of Schwartz (1987) and Stockton and Slaughter (1991) may be (1) that we used a slightly different analog of nipecotic acid, cis-4-hydroxynipecotic acid, and (2) that the extracellular $\mathrm{Na}^{+}$concentration in the slice preparation could be lowered more effectively than in the eyecup preparation used by Stockton and Slaughter (1991).

There is a marked difference between the PTX-insensitive GABA-induced $I / V$ curves measured by Malchow and Ripps (1990) and the curves presented in this article. We outline in the Discussion some reasons for this difference in the context of the problems of measuring and interpreting carrier-mediated $I / V$ curves.

Summary. The PTX-insensitive GABA-induced current has characteristics similar to the NIP-induced current. The NIPinduced current is absent when choline ${ }^{+}$is substituted for $\mathrm{Na}^{+}$, indicating that the NIP current is $\mathrm{Na}^{+}$dependent. These two findings strongly suggest the presence in salamander HCs of electrogenic GABA transporters.

We did not attempt to characterize (stoichiometry and $K_{m}$ values) the transporter completely since that would be out of the scope of the present study. Determining the reversal potential of the transporter is not relevant in this study of an intact system: the $\mathrm{HCs}$ in the slice probably strongly control the extracellular GABA concentration such that the reversal potential of the transporter shifts with the membranc potential and is always held close to the holding potential.

\section{Change in dynamics of $\mathrm{HC}$ light response}

The experiments described so far indicate that GABA acts at two sites on the $\mathrm{HC}$ : (1) via a $\mathrm{GABA}_{\mathrm{A}}$ receptor and (2) via an electrogenic GABA transporter. In this section we show that the two GABAergic components in the $\mathrm{HC}$ membrane form a regenerative autofeedback loop that slows down the $\mathrm{HC}$ light response kinetics under current-clamp conditions. The autofeedback loop can be opened in at least two independent ways; (1) by blocking the $\mathrm{GABA}_{\mathrm{A}}$ receptor with PTX, and (2) by inhibiting the GABA transport with NIP. Both interruptions of the loop will cause faster $\mathrm{HC}$ light responses, indicating that the proposed GABAergic positive feedback loop indeed controls the $\mathrm{HC}$ response kinetics.

In addition to these two cxperiments, the autofeedback loop can also be manipulated in at least two ways that involve only the recorded cell; (3) by changing $E_{\mathrm{Cl}}$ from $-17.3 \mathrm{mV}$ to -49.2 $\mathrm{mV}$ in the recorded $\mathrm{HC}$, and (4) by inhibiting the GABA transporter by voltage clamping the $\mathrm{HC}$. These four experiments will show that the loop indeed exists and that the complete loop is located in the recorded cell.

\section{(1) Opening of the loop by blocking the GABA-gated $\mathrm{Cl}^{-}$ conductance}

Figure 7 shows that PTX, which interrupts the relation between the extracellular GABA concentration and the $\mathrm{Cl}^{-}$conductance, speeds the voltage response of a $\mathrm{HC}$. In the dark, the $\mathrm{HC}$ rested at $-18 \mathrm{mV}$. The light ONset response in a $50 \mu \mathrm{M}$ GABA Ringer's solution is very slow and shows the characteristic regenerative shape. All responses had an initial fast hyperpolarizing component, followed by a slowly hyperpolarizing phase that ended in a fast hyperpolarization. The time course and the sizes of the various parts of the responses varied somewhat between the experiments.

In the presence of $100 \mu \mathrm{M}$ PTX, the HC response became fast and large. The regenerative shape of the response was absent. All HCs tested responded in this manner in 50-100 $\mu \mathrm{M} \mathrm{GABA}$ 

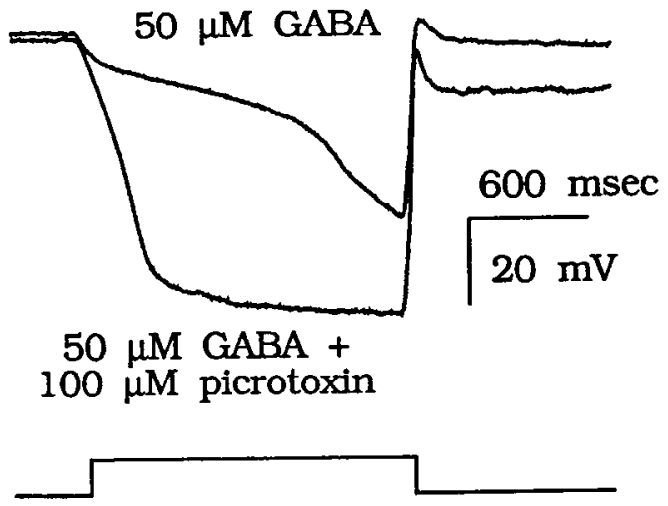

Figure 7. The cffect of PTX on the GABA-induced slowdown of the HC light response under current clamp. cAMP at $1 \mathrm{mM}$ was present in the patch pipette, and $E_{C}$ was set at $-17.3 \mathrm{mV}$. The resting membrane potential was $-18 \mathrm{mV}$.

and $100 \mu \mathrm{M}$ PTX. Note that the OFFset response is fast in both conditions and that PTX did not change the dark membrane potential severely.

These results are consistent with the proposed GABAergic positive feedback loop. PTX blocks the GABA $\mathrm{A}_{\mathrm{A}}$ receptor and therefore opens the GABAergic positive autofeedback loop. Since it is the positive autofeedback loop that slowed the $\mathrm{HC}$ responses kinetics, the $\mathrm{HC}$ response will become fast with PTX. The HC response is large in a PTX Ringer's solution since PTX abolishes the shunt due to the large $\mathrm{Cl}^{-}$conductance.

The absence of a major effect of PTX on the dark membrane potential is presumably due to an additional effect of PTX on the feedback pathway from HCs to cones. PTX will depolarize the cones and therefore increase the glutamate release, which results in a depolarization of the $\mathrm{HCs}$.

The effect of PTX on the kinetics of the $\mathrm{HC}$ response shows that a $\mathrm{GABA}_{\mathrm{A}}$ receptor is involved in modulation of the $\mathrm{HC}$ kinetic behavior.

\section{(2) Application of NIP opens the loop by inhibiting GABA transport}

Figure 8 shows the light responses of a $\mathrm{HC}$ with and without $100 \mu_{\mathrm{M}}$ NIP. The HC, bathed in $100 \mu_{\mathrm{M}} \mathrm{GABA}$, rested at -20 $\mathrm{mV}$. The voltage response shows the characteristic regenerative shape. Application of $100 \mu \mathrm{M}$ NIP hyperpolarized the HC by 4 $\mathrm{mV}$. The response became faster, the regenerative shape of the $\mathrm{HC}$ response was completely absent, and the maximal response amplitude was reduced.

The effect of NIP on the kinetics of the $\mathrm{HC}$ response can be explained as follows. The results presented in Figure 6 show that NIP competes with GABA for the binding site on the transporter. In other words, the transporter does not distinguish between NIP and GABA. At a given membrane potential, the transporter has distributed GABA such that there is a steady state. Adding NIP to the outside medium will result in an increase of the apparent extracellular GABA concentration since the transporter cannot distinguish between NIP and GABA. In order to reestablish the steady state, the cell will take up GABA and NIP and thus reduce the extracellular GABA concentration. The GABAergic positive feedback loop will therefore become less effective, resulting in fast $\mathrm{HC}$ responses. The extracellular GABA concentration will not be reduced severely during the light response because the transporter will transport both GABA
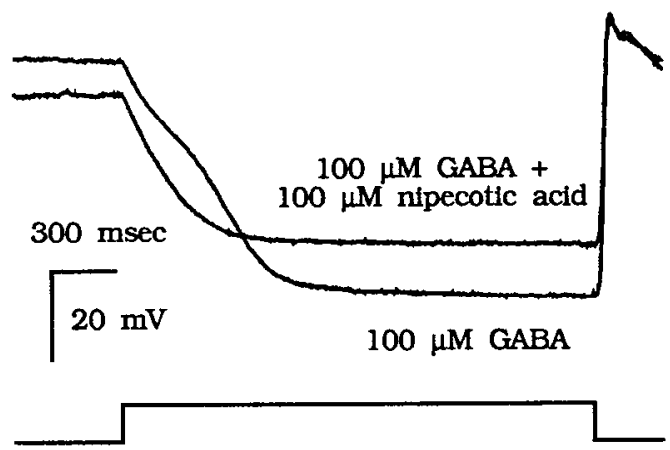

Figure 8. The effect of NIP on the GABA-induced slowdown of the $\mathrm{HC}$ light response of under current clamp. cAMP at $1 \mathrm{~mm}$ was present in the patch pipctte and $E_{\mathrm{Cl}}$ was set at $-17.3 \mathrm{mV}$. The resting membrane potential was $-20 \mathrm{mV}$.

and NIP. Therefore, the change in extracellular GABA concentration during the light response will be small, resulting in a smaller maximal response amplitude because the relatively large $\mathrm{Cl}^{-}$conductance will be present during the whole response.

The experiment of Figures 7 and 8 shows that the $\mathrm{GABA}_{\mathrm{A}}$ receptor and the GABA transporter are involved in the modulation of the $\mathrm{HC}$ kinetics but does not show on which cell the $\mathrm{GABA}_{\mathrm{A}}$ receptor and the GABA transporter are located. The two following experiments suggest that the $\mathrm{GABA}_{\mathrm{A}}$ receptor and the GABA transporter are located in the same cell because the changes induced are localized to the recorded cell alone.

\section{(3) Changing $\mathrm{E}_{C 1}$ from $-17.3 \mathrm{mV}$ to $-49.2 \mathrm{mV}$ in the recorded cell makes the loop ineffective}

By lowering the $\mathrm{Cl}^{-}$concentration in the patch pipette, it was possible to change $E_{\mathrm{Cl}}$ from $-17.3 \mathrm{mV}$ to $-49.2 \mathrm{mV}$ in the recorded cell alone. Figure 9 shows the light response for an $\mathrm{HC}$ with $E_{\mathrm{Cl}}$ set at $-49.2 \mathrm{mV}$. The HC's dark resting membrane potential was $-21 \mathrm{mV}$. Adding $50 \mu \mathrm{M}$ GABA caused a hyperpolarization instead of a depolarization, and the light response kinetics did not slow down.

With $E_{\mathrm{C}}$ at $-17.3 \mathrm{mV}, \mathrm{HCs}$ will depolarize to application of GABA, resulting in a positive feedback to themselves. However, with $E_{\mathrm{C}}$ at $-49.2 \mathrm{mV} \mathrm{HCs}$ will hyperpolarize to applied GABA, resulting in a negative feedback to themselves. In addition to this, the extracellular GABA concentration will be lowered since (1) GABA release will be reduced by the hyperpolarization of the $\mathrm{HC}$ and (2) the low intracellular $\mathrm{Cl}^{-}$concentration may reduce the GABA release via the GABA transporter because $\mathrm{Cl}^{-}$is cotransported with GABA and $\mathrm{Na}^{+}$(Kanner and Schuldiner, 1987; Keynan and Kanner, 1988). Thus, lowering the intracellular $\mathrm{Cl}^{-}$concentration will make the GABAergic autofeedback loop ineffective. This results in fast $\mathrm{HC}$ responses even in a GABA Ringer's solution.

This experiment suggests that the complete loop must be in the recorded cell since in only that cell $E_{\mathrm{Cl}}$ was lowered.

\section{(4) Voltage clamping the recorded cell makes the loop ineffective}

A second way to show that the loop is located in the recorded cell, is to compare the kinetics of the light response under voltage-clamp and under current-clamp conditions. Figure 10 shows the $\mathrm{HC}$ light responses under voltage and under current clamp. Under voltage clamp the membrane potential was held at the resting membrane potential $(-26 \mathrm{mV})$. The response under 


\section{control}

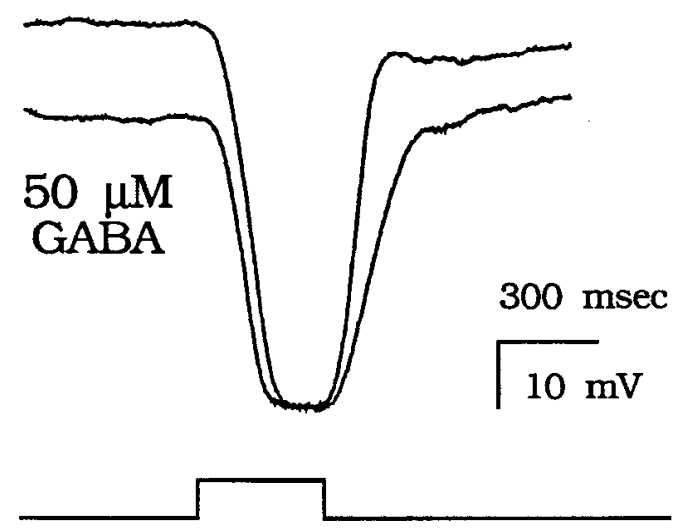

Figure 9. The effect of $50 \mu \mathrm{M}$ GABA on the HC light response under current clamp when $E_{\mathrm{Cl}}$ was set at $-49.2 \mathrm{mV}$ by lowering the intracellular $\mathrm{Cl}^{-}$concentration. cAMP at $1 \mathrm{~mm}$ was present in the pipette. The resting membrane potential in the control Ringer's solution was -21 $\mathrm{mV}$.

voltage clamp has been inverted and superposed on the response under current clamp. The responses were scaled such that the first phase of the ONset of the responses overlapped. The response under current clamp showed the characteristic regenerative shape, whereas the response under voltage clamp steadily increased.

The GABAergic positive feedback loop will determine the kinetics of the $\mathrm{HC}$ response under current-clamp conditions. Under voltage-clamp conditions, the membrane potential is held constant, so the transporter will not change the extracellular GABA concentration. Thus, the GABA concentration will remain high, the positive feedback loop will be ineffective and the characteristic regenerative shape of the $\mathrm{HC}$ response will be absent. This experiment shows that the HC kinetics are controlled by a mechanism involving the GABA transporter in the recorded cell since the GABA transporter in the recorded cell alone will be uncoupled by voltage clamp.

The stcady increase in the response amplitude under voltage clamp may be due to some remaining electrical coupling of the $\mathrm{HCs}$ or may indicated that the HCs are chemically coupled. Chemical coupling could result from the following mechanism. GABA released upon depolarization by the neighboring HCs due to light stimulation may have two effects: (1) it will open the $\mathrm{Cl}^{-}$conductance causing a depolarization, and (2) it will stimulate GABA uptake by the GABA transporter in the recorded cell, resulting in an inward current, and thus depolarize the recorded cell.

\section{Discussion}

Figure 11 summarizes our results: a GABA transporter and a $\mathrm{GABA}_{\mathrm{A}}$ receptor, both located in the membrane of the same $\mathrm{HC}$, form a regenerative loop that can control the kinetics of the $\mathrm{HC}$ response. The GABA transporter couples the membrane potential $\left(V_{m}\right)$ to the extracellular GABA concentration ([GABA]), the GABA receptor couples the extracellular GABA concentration to membrane current $\left(i_{\mathrm{Cl}}\right)$, and the $\mathrm{HC}$ membrane couples membrane current to the membrane potential to complete the loop. The presence of the components of the loop has been shown in Results. Here, we show how $\mathrm{HC}$ response kinetics can be affected by changes in driving force of the $\mathrm{Cl}^{-}$ions gated

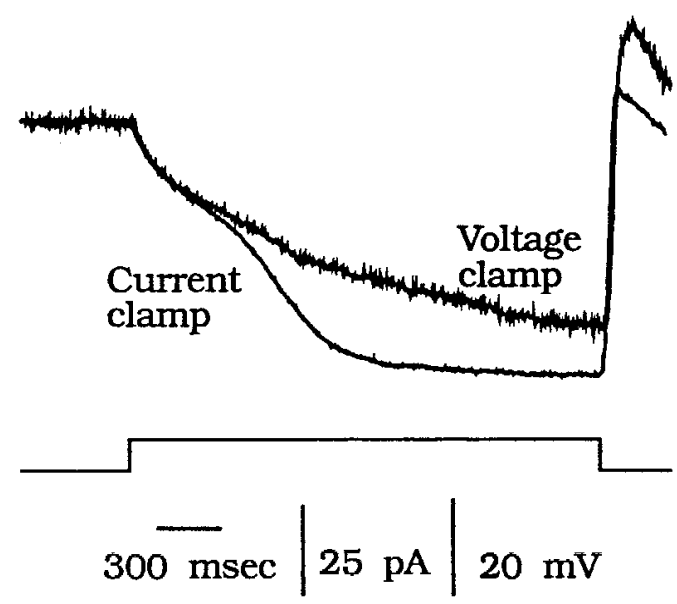

Figure 10. The effect of voltage clamp on the GABA-induced slowdown of the HC light response. Two traces of light responses of the same $\mathrm{HC}$ are shown; one of the $\mathrm{HC}$ light response under voltage clamp, and one of the $\mathrm{HC}$ light response under current clamp. The trace under voltage clamp was inverted and scaled such that the onset of both responses overlapped. The holding potential of the cell under voltage clamp was identical as the resting membrane potential of that cell under current clamp $(-26 \mathrm{mV}) . E_{\mathrm{Cl}}$ was set at $-17.3 \mathrm{mV}$.

by the GABA receptor, and by changes in membrane conductances gated by other synaptic inputs to the $\mathrm{HC}$.

The slope of each phase of the $H C$ response is determined by the driving force and the relative conductance at the GABA-gated channels

A typical HC response, showing the five characteristic slope regions, is shown in Figure 12. Based on the experiments described in this article, it is possible to describe the various events leading to the observed $\mathrm{HC}$ response shape.

The fast hyperpolarizing phase 1 (Fig. 12, arrow 1), following light ONset, is generated when the initially high glutamate-gated conductance is rapidly reduced as light hyperpolarized the photoreceptors. This response component is relatively small because the GABA-gated $\mathrm{Cl}^{-}$conductance, controlled by the loop,

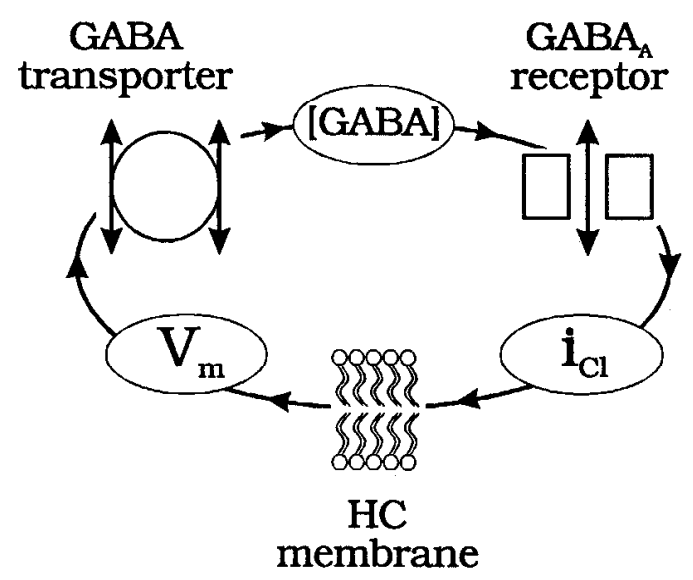

Figure 11. The GABAergic positive feedback loop with all its components and variables. Each component couples two variables. The GABA transporter couples the extracellular GABA concentration $\left([G A B A /)\right.$ to the membrane potential $\left(V_{m}\right)$, the $\mathrm{GABA}_{\mathrm{A}}$ receptor couples the $\mathrm{Cl}^{-}$current $\left(i_{C l}\right)$ the GABA concentration, and the $\mathrm{HC}$ membrane couples the membrane potential $\left(V_{m}\right)$ to the $\mathrm{Cl}^{-}$current. 


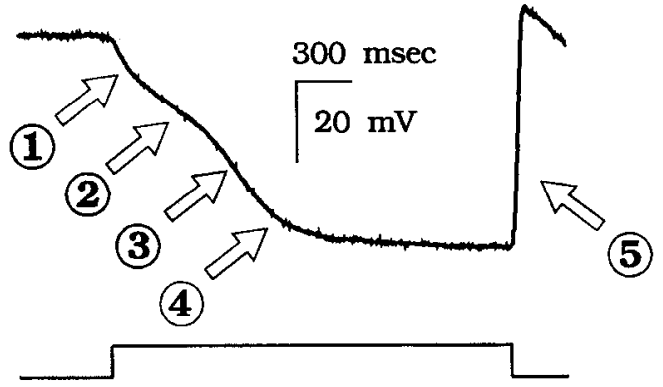

Figure 12. HC light response (from Fig. 10) with $100 \mu \mathrm{M}$ GABA. Arrow 1, Initial fast hyperpolarization is generated by closing of the glutamatc channels by photoreceptor input. The large $\mathrm{Cl}^{-}$conductance shunts the response. Arrow 2, Secondary slow hyperpolarization is generated by the GABAergic positive feedback loop. The response is slow since, as is explained in the text, the membrane potential is still close to $E_{\mathrm{CL}}$. Arrow 3, Fast hyperpolarization is generated by the loop. Now the membrane potential is far from $E_{\mathrm{a}}$ and generates a fast response. Arrow 4 , Final slow hyperpolarization is generated by the GABAergic positive feedback loop. The $\mathrm{HC}$ response is slow since the $\mathrm{Cl}^{-}$conductance is very small. Modulation of the $\mathrm{Cl}^{-}$conductance will hardly modulate the membrane potential. Arrow 5, Fast OFFset response of the HC. The $\mathrm{HC}$ response is fast since the $\mathrm{Cl}^{-}$conductance does not shunt the $\mathrm{HC}$ response any longer.

is high in the dark. For comparison, when the GABA-gated $\mathrm{Cl}^{-}$ conductance was blocked by PTX, phase 1 of the response became large as shown in Figure 7.

The initial photoreceptor-induced hyperpolarization sets in motion the regenerative action of the loop whereby GABA is removed from the extracellular space by the GABA transporter, and the decrease in GABA concentration leads to a decrease in the GABA-gated $\mathrm{Cl}^{-}$conductance. From here on, if it is assumed that the loop has relatively long time constant (see Appendix), then the slope of the response will be determined by the driving force on $\mathrm{Cl}^{-}$. The magnitude of the change in current per time unit elicited by a decrease of extracellular GABA concentration will be proportional to the driving force on $\mathrm{Cl}^{-}$.

Strictly speaking, phases $2-4$ are expressions of one continuous process. However, for clarity, we will treat this continuous process as three separate states. The slope of the response during phase 2 is shallow because the driving force is small, near $8 \mathrm{mV}$ $\left(E_{\mathrm{Cl}}=-17 \mathrm{mV} ; V_{m}=-25 \mathrm{mV}\right)$. A give reduction in the extracellular GABA concentration per time unit will only result in a small hyperpolarization. Phase 3 of the response is initiated when the membrane has hyperpolarized to around $-45 \mathrm{mV}$. Here, the driving force has increased nearly four times to 28 $\mathrm{mV}$, so the same incremental decrease in GABA concentration per time unit will lead to four times the decrease in $\mathrm{Cl}^{-}$current, resulting in fast hyperpolarization. The shallow response during phase 4 occurs because the $\mathrm{Cl}^{-}$current has become so small, due to the low GABA concentration in the extracellular space, that it no longer significantly modulates the membrane potential.

Finally, at light OFFset there is a large and rapid return of the membrane potential to the dark level as shown by phase 5 . The response is due to the increase of the glutamate-gated conductance elicited by the rapid depolarization of the photoreceptors. The $\mathrm{HC}$ depolarizes strongly because there is little GABA-gated $\mathrm{Cl}^{-}$conductance to shunt the photoreceptor-elicited response since the $\mathrm{HC}$ is very hyperpolarized. A spike generated by the photoreceptors at light OFFset (Wu, 1988; Wu and Yang, 1988) as well as feedback from the cones (Kamermans et al., 1989b) and the $\mathrm{Ca}^{2+}$ current in HCs may also contribute to the speed of the OFFset response.

Phases 1 and 5 of the $\mathrm{HC}$ light response shown in Figure 12 represent two extreme cases showing how different relative magnitudes of the glutamate- and GABA-elicited conductances can affect the magnitude of the photoreceptor input. During phase 1 the GABA-elicited conductance is relatively high, so the glutamate-elicited response is small; during phase 5 the GABAelicited conductance is minimal, so the glutamate-elicited response is quite large. Also, under other conditions, the magnitude of the GABA-gated conductance, relative to the other membrane conductances, determines the behavior of the $\mathrm{HCs}$ as described below,

\section{Effects of glycine and strychnine on the $H C$ response kinetics}

Several authors have reported that $\mathrm{HCs}$ receive a glycinergic input that slows down the $\mathrm{HC}$ light response (Witkovsky and Stone, 1987; Yang and Wu, 1989b; Gilbertson et al., 1990; Stockton and Slaughter, 1991). This slowdown might be caused by a glycine-elicited depolarization of the $\mathrm{HC}$ membrane. This depolarization will increase the extracellular GABA concentration since the GABA transporter will release GABA. The depolarized $\mathrm{HC}$ membrane and the resulting high GABA concentration will increase the GABA-gated $\mathrm{Cl}^{-}$conductance and decrease the driving force for $\mathrm{Cl}^{-}$. As explained above, this results in slow $\mathrm{HC}$ responses. Strychnine makes the $\mathrm{HC}$ response fast again by hyperpolarizing the $\mathrm{HC}$, increasing the driving force for $\mathrm{Cl}^{-}$and decreasing the $\mathrm{Cl}^{-}$conductance (Yang and $\mathrm{Wu}$, 1989b).

\section{Effect of dark adaptation on the kinetics of the $H C$ response}

Yang and Wu (1989b) have shown that $\mathrm{HC}$ light responses are very slow in the dark-adapted retina but become fast in the light-adapted state. They also show that the slow HC responses can be simulated by increasing the extracellular GABA concentration in the light-adapted retina. Yazulla (1985) showed that the $\mathrm{Ca}^{2+}$-independent GABA release is high in the dark-adapted retina and that the GABA release is reduced by light. Therefore, $\mathrm{HC}$ responses are probably slow in the dark-adapted retina because the GABA concentration near the $\mathrm{HCs}$ is high during dark adaptation.

GABA release from $\mathrm{HCs}$ is increased in the dark-adapted retina (Yazulla, 1985). Although this could be caused by different resting membrane potentials of the HC's in both adaptation state, dopamine will inhibit the GABA release from $\mathrm{HCs}$ also directly (Yazulla and Kleinschmidt, 1982; O'Brien and Dowling, 1985). The relation between the extracellular GABA concentration and the membrane potential may therefore be different in both adaptation states. So, even if the HCs rest at the same potentials in both adaptation states, the extracellular GABA concentration, and thus the importance of the GABAergic positive feedback loop, may differ significantly.

\section{The GABAergic positive autofeedback loop requires restricted extracellular space to contain the extracellular $G A B A$ concentration}

The GABA concentration, established by the transporter, will affect the $\mathrm{GABA}_{\mathrm{A}}$ receptor only if release is confined to a limited extracellular space. The invagination at the cone terminal is a likely site constraining release. If leakage from the invagination is small, the transporter will be able to maintain a state close to equilibrium between $\mathrm{GABA}, \mathrm{Na}^{+}$, and $\mathrm{Cl}^{-}$even if extracel- 
lular GABA is added to the bath. Addition of GABA in the Ringer's solution will result in a reduction of $G A B A$ release out of the terminal and thus to an increase of the extracellular GABA concentration in the synaptic terminal. However, HCs control the extracellular GABA concentration in the terminal with GABA transporters with a relative high capacity (Fig. 6). Therefore, it is very likely that the GABA concentration in the terminal is mostly determined by the $\mathrm{HC}$ membrane potential and not by the bath GABA concentration.

We suggest that the GABA transporter in HCs simply redistribute GABA across the HC membrane as a function of membrane potential. In the light, GABA is moved from the extracellular compartment to the intracellular compartment, and in the dark GABA is moved in the opposite way.

\section{The $\mathrm{I} / \mathrm{V}$ relation of the $P T X$-insensitive $G A B A$-induced current}

The experiments that characterize the GABA transporter presented in this article differ dramatically from those in the work of Malchow and Ripps (1990). In fact, the curves in neither report are $I / V$ curves for the transporter, but $I / V$ curves for the GABA-induced current. These curves differ in shape because of the different experimental conditions: in our experiments with intact $\mathrm{HCs}$, the transporter will always be near equilibrium since it controls extracellular GABA concentration; in Malchow and Ripps' study, the transporter will never be at equilibrium since their experimental conditions control both the intra- and extracellular GABA concentrations with no GABA in the cell.

Malchow and Ripps (1990) suggest that the driving force for the transporter approaches zero when the membrane potential approaches the equilibrium potential for $\mathrm{Na}^{+}$, but the driving force for the transporter depends upon the equilibrium potentials for both $\mathrm{Na}^{+}$and GABA. With zero GABA in the cell, its driving force will be infinite at all potentials. The work of Schultz (1986) proposes an alternative explanation for the results of Malchow and Ripps. If we assume that the unloaded transporter is negatively charged, depolarization will move most of the transporters to the inside of the membrane, where they will be unavailable for GABA uptake. Puffs of GABA will induce smaller currents at more positive potentials.

Our conditions are quite different. With GABA in the cell, the transporter will be loaded in the cell and therefore becomes uncharged, so there will be no redistribution of transporters with membrane depolarization; instead, more GABA will be released with depolarization, generating an outward current. Under these conditions, adding extracellular GABA will reduce this outward current. Thus, we will measure a GABA-induced inward current. The negative slope of our GABA-induced inward current suggests that the reduction of the GABA efflux by GABA (or NIP) may be voltage dependent. This voltage dependence may be a consequence of the voltage-dependent steps in the transporter cycles (see Blatt, 1986; Schultz, 1986).

Unfortunately, the techniques required for a full description of the transporter in general, and for its GABA-induced current in particular, are not available. We need a complete description of the voltage dependence and cooperativity of the binding of $\mathrm{GAB} \Lambda, \mathrm{Na}^{+}$, and $\mathrm{Cl}^{-}$. Furthermore, the voltage dependence of the translocation step of the transporter and all the $K_{m}$ values of the different binding steps must be known. With these parameters and a realistic model for the transporter cycles, we could describe the $I / V$ curves of Malchow and Ripps (1990). Such parameters cannot be determined in the retinal slice because the intra- and extracellular concentrations GABA are not under experimental control. Our results strongly suggest the presence of a transporter, but the details of its operation are beyond the aim and scope of this study.

\section{The GABA transporter and the GABA receptor mediate chemical coupling between $H C S$}

GABA release by one $\mathrm{HC}$ may act at the $\mathrm{GABA}_{\mathrm{A}}$ receptor of its neighbors, forming a sign-preserving chemical synapse between HCs. Evidence for such coupling is shown in Figure 10, where we have uncoupled the gap junctions between HCs using cAMP, and where we have opened the loop in the recorded cell by voltage clamping. This cell still shows a slowly developing outward current in response to light. This current is most likely due to GABAergic input from neighboring HCs since when the GABA-gated $\mathrm{Cl}$ conductance is blocked by PTX, the voltage and current traces are almost similar (not shown).

This chemical coupling between $\mathrm{HCs}$ will obey constraints similar to those described above for the loop within HCs. For example, coupling will be strongest when the GABA conductance is large relative to the other membrane conductances, and when the driving force for $\mathrm{Cl}^{-}$is large. We have not yet measured the relative contribution of this chemical coupling to the size of the $\mathrm{HC}$ receptive fields.

In conclusion, the described GABAergic positive feedback loop is a major pathway in the outer plexiform layer in tiger salamander retina. The GABAergic positive feedback loop may have important effects on both the temporal as well as the spatial properties of HCs. Modulation of this loop, for instance by dopamine, may mediate changes in kinetics, and receptive field sizes of HCs during light/dark adaptation.

\section{Appendix}

\section{Equations}

We present here simulations of $\mathrm{HC}$ responses. Equations accounting for the transfer function (kinetics and gain) of each component of the loop are derived, and these equations are then used to generate in detail the light response waveform measured in this article. The equations establish formal relationships between the membrane potential as functions of membrane conductances (Eq. 1), the $\mathrm{Cl}^{-}$conductance as function of extracellular GABA concentration (Eq. 2), and the extracellular GABA concentration as a function of membrane potential (Eq. 3). These relationships are discussed in detail, and the results of the simulations are presented below.

\section{The resistive model for the $H C$ membrane}

A simple resistive network was used to simulate the $\mathrm{HC}$ light responses. The $\mathrm{HC}$ membrane is modeled as three conductances in parallel (Fig. 13); a glutamate-sensitive cation conductance $\left(g_{\text {ion }}\right)$, a passive $\mathrm{K}^{+}$conductance $\left(g_{\mathrm{K}}\right)$, and a GABA-sensitive $\mathrm{Cl}^{-}$ conductance $\left(g_{\mathrm{C}}\right)$. Each conductance is in series with a battery. The potential of the batteries represents the equilibrium potentials for the permeable ions. The voltage-gated currents are ignored since all of them, except the $\mathrm{Ca}^{2+}$ current, are not activated in the range of the physiological membrane potentials. The membrane potential of the model $\mathrm{HC}$ is therefore given by

$$
V_{m}=\frac{\left(g_{\text {ion }} \cdot E_{\mathrm{ion}}+g_{\mathrm{K}} \cdot E_{\mathrm{K}}+g_{\mathrm{Cl}} \cdot E_{\mathrm{Cl}}\right)}{\left(g_{\mathrm{ion}}+g_{\mathrm{K}}+g_{\mathrm{Cl}}\right)},
$$

where $E_{\text {ion }}$ is the equilibrium potential of the glutamate-gated conductance $(=0 \mathrm{mV}), E_{\mathrm{Cl}}$ is the equilibrium potential of the 


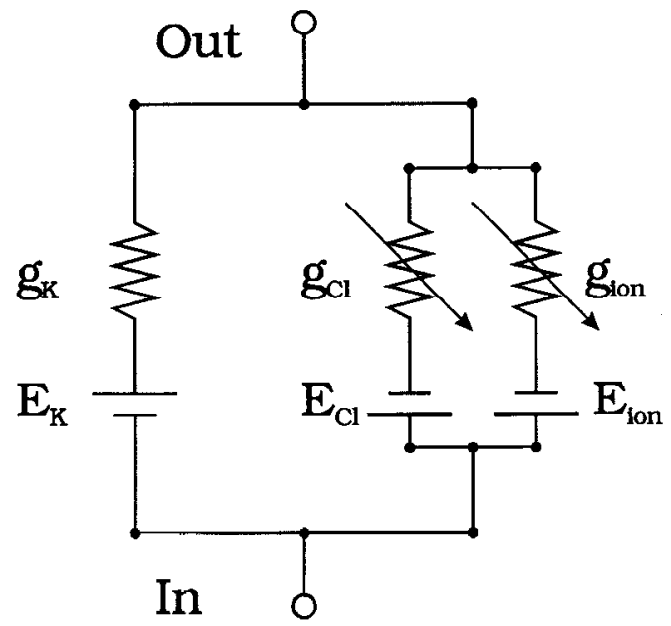

Figure 13. Model network to simulate $\mathrm{HC}$ light responses. $g_{\mathrm{K}}$ is the conductance of the potassium channcls, $g_{\mathrm{Cl}}$ is the GABA-gated $\mathrm{Cl}^{-}$conductance, and $g_{\text {ion }}$ is the glutamate-gated conductance. $E_{\mathrm{K}}, E_{\mathrm{C}}$, and $E_{\text {ion }}$ are the equilibrium potentials for the various conductances.

GABA-gated $\mathrm{Cl}^{-}$conductance $(=-17 \mathrm{mV}), E_{\mathrm{K}}$ is the equilibrium potential of the potassium channels $(=-97 \mathrm{mV}), g_{\text {iun }}$ is the conductance of the glutamate channels, $g_{\mathrm{C} 1}$ is the conductance of the GABA-gated $\mathrm{Cl}^{-}$channels, and $g_{\mathrm{K}}$ is the conductance of the potassium channels (=1.0 units).

GABA $A^{-}$gated $\mathrm{Cl}^{-}$conductance

It is assumed that the GABA-gated $\mathrm{Cl}^{-}$conductance $\left(g_{\mathrm{Cl}}\right)$ is related to the extracellular GABA concentration near the GA$\mathrm{BA}_{\mathrm{A}}$ receptor $\left([\mathrm{GABA}]_{o}\right.$ ) by the relation given by Equation 2 . This is in accordance with a Hill coefficient of 2.1 for the GABA for HCs in tiger salamander (Gilbertson et al., 1990):

$$
g_{\mathrm{Cl}}=g_{\mathrm{Cl}}^{\max } \cdot \frac{[\mathrm{GABA}]_{o}^{2}}{[\mathrm{GABA}]_{o}^{2}+K_{m}^{2}},
$$

where $g_{\mathrm{Cl}}^{\mathrm{Max}}$ is the maximal $\mathrm{Cl}^{-}$conductance (=12.5 units) and $K_{m}$ is the half-maximal GABA concentration $(=40 \mu \mathrm{M})$.

\section{The GABA transporter}

It is assumed that the GABA transporter in HCs has similar characteristics as the GABA transporter described by Kanner and coworkers. One uncharged GABA molecule is cotransported with $2 \mathrm{Na}^{+}$ions and $1 \mathrm{Cl}^{-}$ion (Kanner and Schuldiner, 1987; Keynan and Kanner, 1988). Based on this stoichiometry, the electrochemical potential for the transporter can be derived:

$$
\mu_{\text {transporter }}^{e}=\mu_{\mathrm{GABA}}^{e}+\mu_{\mathrm{Na}}^{e}+\mu_{\mathrm{Cl}}^{e},
$$

with

$$
\begin{aligned}
\mu_{\mathrm{GABA}}^{e} & =R \cdot T \cdot \ln \frac{[\mathrm{GABA}]_{i}}{[\mathrm{GABA}]_{o}}, \\
\mu_{\mathrm{Na}}^{e} & =n \cdot R \cdot T \cdot \ln \frac{[\mathrm{Na}]_{i}}{[\mathrm{Na}]_{o}}+n \cdot F \cdot V_{m}, \\
\mu_{\mathrm{Cl}}^{e} & =m \cdot R \cdot T \cdot \ln \frac{[\mathrm{Cl}]_{i}}{[\mathrm{Cl}]_{o}}-m \cdot F \cdot V_{m},
\end{aligned}
$$

where $\mu_{\text {transp }}^{e}$ is the electrochemical potential of the transporter, $\mu_{\mathrm{GABA}}^{e}$ is the electrochemical potential of GABA, $\mu_{\mathrm{Na}}^{e}$ is the elec- trochemical potential of $\mathrm{Na}^{+}, \mu_{\mathrm{C}}^{e}$ is the electrochemical potential of $\mathrm{Cl}^{-},[\mathrm{GABA}]_{i}$ is the intracellular GABA concentration $(=10$ $\mathrm{mM}),[\mathrm{GABA}]_{o}$ is the extracellular GABA concentration, $[\mathrm{Na}]_{i}$ is the intracellular $\mathrm{Na}^{+}$concentration $(=13.54 \mathrm{mM}),[\mathrm{Na}]_{o}$ is the extracellular $\mathrm{Na}^{+}$concentration $(=108 \mathrm{mM}),[\mathrm{Cl}]_{i}$ is the intracellular $\mathrm{Cl}^{-}$concentration $(-60 \mathrm{~mm}),[\mathrm{Cl}]_{0}$ is the extracellular $\mathrm{Cl}^{-}$concentration $(=116 \mathrm{~mm}), n$ is the number of $\mathrm{Na}^{+}$ions transported per GABA molecule $(=2), m$ is the number of $\mathrm{Cl}^{-}$ ions transported per GABA molecule $(=1)$, and $R, T$, and $F$ have their usual meaning.

It is assumed that the GABA transporter can be described completely by Equation 3, that is, that the transporter is completely symmetrical and always near equilibrium. As discussed earlier, this assumption may be realistic since the GABA release sites of the $\mathrm{HCs}$ are presumably located on the $\mathrm{HC}$ dendrites in the cone synaptic terminal. Because the cone synaptic terminal is an enclosed structure, it is likely that the GABA leakage out the terminal is limited. The HCs therefore control to a great extent the GABA concentration in the terminal. However, increasing the bath GABA concentration will reduce the GABA leakage out of the terminal and result in a slight increase of the GABA concentration in the synaptic terminal. If the transporter is in equilibrium, then Equation 4 must hold:

$$
\mu_{\text {transp }}^{e}=0 \text {. }
$$

Finally, we assumed that the time constant of the GABA release (and the diffusion of GABA in the extracellular space) can be described by a first-order lowpass filter with a time constant of $\tau_{\mathrm{GABA}}$ and that the concentrations of $\mathrm{Na}^{+}, \mathrm{Cl}^{-}$, and $\mathrm{GABA}$ are all well above the $K_{m}$ values for the binding sites on the transporter. If the concentrations for the various substrates were well below the $K_{m}$ values, then the transporter would not have behaved symmetrically. That may result in different transport rates at different directions and potentials, which may express itself in a variable time constant of the loop. Since, as we will show below, the loop is much faster then the $\mathrm{HC}$ response, small changes in the time constant of the transporter will hardly be visible in the $\mathrm{HC}$ response.

Combining Fquations 3 and 4 and the above assumptions gives the relation between the membrane potential of the $\mathrm{HC}$ and the extracellular GABA concentration:

$$
\begin{aligned}
{[\mathrm{GABA}]_{o}=} & \frac{[\mathrm{GABA}]_{i} \cdot[\mathrm{Na}]_{i}^{n} \cdot[\mathrm{Cl}]_{i}^{m}}{[\mathrm{Na}]_{o}^{n} \cdot[\mathrm{Cl}]_{o}^{m}} \exp \left(\frac{(n-m) \cdot V_{m}}{(R T / F)}\right) \\
& -\tau_{\mathrm{GABA}} \cdot \frac{d[\mathrm{GABA}]_{o}}{d t}
\end{aligned}
$$

where $\tau_{\text {GABA }}$ is the combined time constant of the GABA transporter, the diffusion of GABA in the extracellular space, and the $\mathrm{GABA}_{\mathrm{A}}$ receptor $(=65 \mathrm{msec})$.

\section{Input to the model $\mathrm{HC}$}

Although Equations 1, 2, and 5 describe the $\mathrm{HC}$ responses rather closely, we made one additional assumption about the input to the HCs. To get a more realistic $\mathrm{HC}$ response, we assumed that the input to the $\mathrm{HC}$ was given by Equation 6, which represents a step change in $g_{\text {ion }}$ filtered by a first-order lowpass filter with a time constant of $\tau_{\text {in }}$. This time constant is the combined time constant of the response of the photoreceptors and the synapse from cones to HCs: 


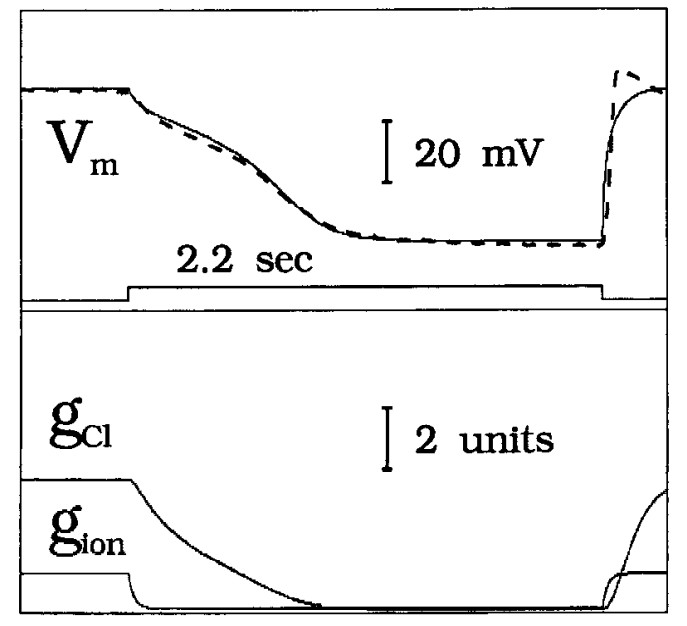

Figure 14. The measured response of an $\mathrm{HC}$ (broken line) and stimulated response of the model HC (solid line) to light flash of $2200 \mathrm{msec}$. $g_{\text {ion }}$ in the dark is 1.30 units and in the light is 0.17 units; $g_{\mathrm{Cl}}$ in the dark is 4.44 units and in the light is 0.12 units; $V_{\mathrm{HC}}$ in the dark is $-25.5 \mathrm{mV}$ and in the light is $-76.7 \mathrm{mV} ; \tau_{\text {GABA }}$ is $65 \mathrm{msec}$.

$$
g_{\text {ion }}=I_{\text {in }}-\tau_{\text {in }} \cdot \frac{d g_{\text {ion }}}{d t}
$$

where $I_{\text {in }}$ is the input to the $\mathrm{HC}(=1.30$ units in the dark; $=0.17$ units in the light) and $\tau_{\text {in }}$ is the combined time constants of the photoreceptor and the synapse of the cone to the $\mathrm{HC}(=25 \mathrm{msec})$.

These equations describe the $\mathrm{HC}$ light response. For simplicity, the feedback pathway from HCs to the cones is ignored in these simulations. This will, however, hardly affect the behavior of the model since the feedback pathway from HCs to the cones will eventually modulate the glutamate input to the HCs. Since $\mathrm{HC}$ responses in GABA Ringer's solution were simulated, the glutamate input to the $\mathrm{HCs}$ will be shunted by the large $\mathrm{Cl}^{-}$ conductance in the $\mathrm{HC}$ membrane and the feedback will hardly be visible. Equations 5 and 6 are solved numerically by the method of Runge-Kutta (Hamming, 1962).

\section{Dependence on the parameter values}

The simulations show that the regenerative $\mathrm{HC}$ responses can be generated with parameter values close to the physiological values. Although we do not know the exact concentrations of all ions at the dendrites, we know that GABA is released upon depolarization (Schwartz, 1987). This means that the reversal potential of the transporter must be in the range of the physiological membrane potentials, presumably always very close to the membrane potential.

The reversal potential of the transporter will depend on the concentrations of all the substrates. If the reversal potential is always close to the membrane potential, then we can estimate the concentrations of GABA and $\mathrm{Na}^{+}$. According to Lam (1972), $[\mathrm{GABA}]_{i}$ must be higher than $3 \mathrm{~mm}$ since the amount of GABA in the retina is equivalent to a uniform concentration of $3 \mathrm{~mm}$. We assumed, as did Schwartz (1987), that $[\mathrm{GABA}]_{i}$ is in the order of magnitude of $10 \mathrm{~mm}$. To create $[\mathrm{GABA}]_{o}$ in the working range of the $\mathrm{GABA}_{\mathrm{A}}$ receptor (between 0 and $100 \mu \mathrm{M}$ ), we had to assume that $[\mathrm{Na}]_{i}$ was $13.54 \mathrm{mM}$. This high value for $[\mathrm{Na}]_{i}$ may be the result of the continuous influx of $\mathrm{Na}^{+}$through the glutamate-gated conductance in the $\mathrm{HC}$ dendrites. If we had assumed a lower value for $[\mathrm{Na}]_{i}$, then $[\mathrm{GABA}]_{i}$ would have to be higher for $[\mathrm{GABA}]_{o}$ to be in the proper range.

$K_{m}$ was chosen to be $40 \mu \mathrm{M}$, close to the value measured by

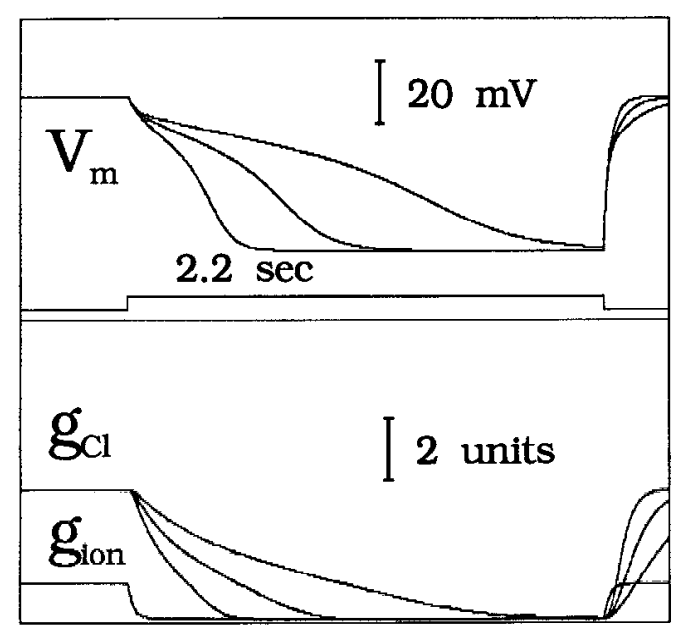

Figure 15. Effect of changing the time constant of the loop $\left(\tau_{\mathrm{GABA}}\right)$ on the model HC light responses to flashes of light of $2200 \mathrm{msec}$. Three simulations are given for values of $\tau_{\mathrm{GABA}}$ of $32.5 \mathrm{msec}, 65 \mathrm{msec}$, and $130 \mathrm{msec}$, respectively. The time to the half-maximal response increased from circa $310 \mathrm{msec}$, to circa $575 \mathrm{msec}$, and finally to circa $1130 \mathrm{msec}$.

Gilbertson et al. (1990) in salamander retinal HCs. $g_{\mathrm{Cl}}^{\mathrm{Max}}, g_{\mathrm{K}}$, and $g_{\text {ion }}$ are all relative numbers, and their values are chosen such the model response fitted the HC response best. $\tau_{\text {in }}$ is chosen such that the first phase of the response was properly fitted. Obviously, changes $\tau_{\text {in }}$ will hardly affect the latter phases of the response. The dependence of the model on $\tau_{\mathrm{GABA}}$ will be discussed below.

\section{Light responses of retinal HCs versus model HCs}

Responses to a "light" flash of $2200 \mathrm{msec}$ duration were simulated. The change in membrane potential of the model $\mathrm{HC}$ to such a stimulus is depicted in the top part of Figure 14. The model $\mathrm{HC}$ rested at $-25.5 \mathrm{mV}$ in the dark. In the bottom part of Figure 14, the changes in the two variable membrane conductances are depicted. The $g_{\text {ion }}$ drops with a time constant of $25 \mathrm{msec}$ from 1.30 units to 0.17 units, whereas $g_{\mathrm{Cl}}$ slowly drops from 4.44 units to 0.12 units with a variable slope. The broken line in the top panel of Figure 14 shows the actual measured retinal $\mathrm{HC}$ response (from Fig. 10). The simulated $\mathrm{HC}$ response follows the response of the HCs in the slice in a GABA Ringer's solution very closely except for the last part of the light off response. Figure 14 shows that, except for the very first phase of the response, the response shape is completely determined by changes in the $\mathrm{Cl}^{-}$conductance in the $\mathrm{HC}$ membrane. So, the properties of the GABAergic positive feedback loop will determine the kinetics of the response after the initial hyperpolarization. The deviation of the simulated response at light off from the measured response is presumably due to the absence of a $\mathrm{Ca}^{2+}$ spike in the input, to the absence of feedback from $\mathrm{HCs}$ to the cones, and to the absence of a $\mathrm{Ca}^{2+}$ current in the HCs.

\section{Gain and time constant of the autofeedback loop}

In this section, the importance of the gain and the time constant of the loop will be discussed.

\section{The effect of the time constant on the $H C$ response}

Figure 15 shows the effects of changing the time constant of the loop on the $\mathrm{HC}$ response. The time constant of the loop is set arbitrarily to $32.5,65$, and $130 \mathrm{msec}$. Increasing or reducing the 


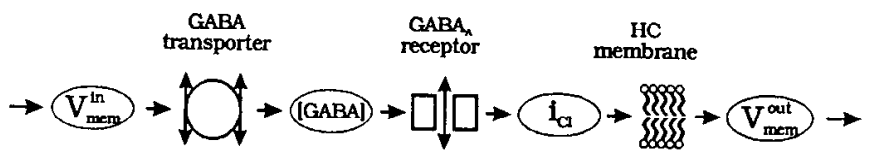

Figure 16. The opened $\mathrm{G} \wedge \mathrm{B} \Lambda$ ergic positive feedback loop with all its components and variables. Membrane potential $\left(V_{m e m}^{i m}\right)$ will affect the extracellular GABA concentration $([G A B A])$ via the transporter, extracellular GABA concentration will affect the $\mathrm{Cl}^{-}$current $\left(i_{C l}\right)$ via the $\mathrm{GABA}_{\mathrm{A}}$ receptor, and the $\mathrm{Cl}^{-}$current will effect the membrane potential $\left(V_{m e m}^{o u t}\right)$ via the membrane. The open loop gain is the millivoltage hyperpolarization of $V_{\text {mem }}^{\text {out }}$ when $V_{\text {mem }}^{\text {in }}$ is hyperpolarized by $1 \mathrm{mV}$.

time constant of the loop has pronounced effects on the second phase of the response, but the overall shape of the response remains more or less unaltered. The time constants of the loop of $32.5 \mathrm{msec}$ to $65 \mathrm{msec}$ to $130 \mathrm{msec}$ result in a time to halfmaximal response respectively of circa $310 \mathrm{msec}$, circa 575 msec, and circa $1130 \mathrm{msec}$. This simulation shows that the time constant of the loop is not linearly related to the time constant of the $\mathrm{HC}$ response and that the characteristic inflection can be generated even with a relative fast loop. As will be shown in the following section, not the time constant but the open loop gain is the crucial parameter that controls the characteristic shape of the $\mathrm{HC}$ response.

\section{The effect of the gain on the $H C$ response}

The open loop gain of the GABAergic positive autofeedback loop is the amount of hyperpolarization of the $\mathrm{HC}$ membrane induced via the GABAergic positive feedback loop when the $\mathrm{HC}$ membrane is hyperpolarized $1 \mathrm{mV}$.

As is shown in Figure 16, the open loop gain depends on (1) the relation between membrane potential $\left(\mathrm{V}_{\mathrm{mem}}^{\mathrm{in}}\right)$ and extracellular GABA concentration ([GABA]), (2) the relation between extracellular GABA concentration and $\mathrm{Cl}^{-}$conductance $\left(i_{\mathrm{Cl}}\right)$, and (3) the relation between $\mathrm{Cl}^{-}$conductance and membrane potential $\left(V_{\mathrm{mem}}^{\mathrm{out}}\right)$. The open loop gain can be constructed by determining the gain of the various components of the loop. That is done graphically in Figure 17: the top left panel gives the relation between the $\mathrm{HC}$ membrane potential and the extracellular GABA concentration (Eq. 5), the top right panel gives the relation between the extracellular GABA concentration and the $\mathrm{Cl}^{-}$conductance (Eq. 2), and the bottom right panel gives the relation between the $\mathrm{Cl}^{-}$conductance and the $\mathrm{HC}$ membrane potential when glutamate conductance is 0.17 (the value of the glutamate conductance during illumination) (Eq. 1). By combining the three curves by following the arrows in Figure 17, the relation between $V_{\mathrm{mem}}^{\mathrm{in}}$ and $V_{\mathrm{mem}}^{\mathrm{mut}}$ was constructed (bottom left panel).

The slope of this curve in the bottom left panel of Figure 17 is the open loop gain of the GABAergic pathway. The curve shows that the gain of the GABAergic positive feedback loop is low if the $\mathrm{HC}$ membrane potential is around $-20 \mathrm{mV}$ ( $\mathrm{x}$-axis in bottom left panel). The gain is low because the $\mathrm{HC}$ membrane potential is close to $E_{\mathrm{Cl}}$. There is little driving force on $\mathrm{Cl}^{-}$, so modulation of $\mathrm{Cl}^{-}$conductance will result in small changes in the $\mathrm{HC}$ membrane potential. If the loop has a relative large time constant, this small change in membrane potential will lead, after some time, to a small change in GABA concentration and thus in a small further hyperpolarization. It will, therefore, take a long time to hyperpolarize the $\mathrm{HC}$ severely. The rate of change in membrane potential is slow if the open loop gain is low.

The open loop gain (the slope of the bottom left curve, Fig.

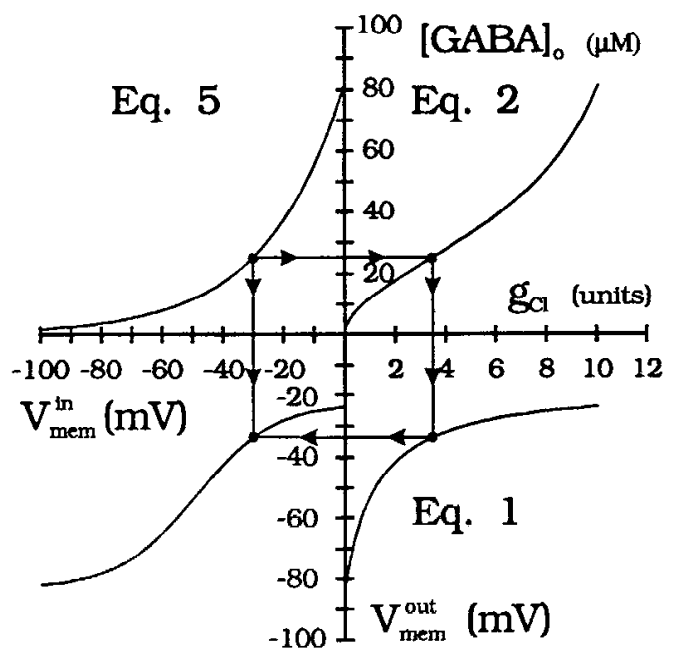

Figure 17. The open loop gain of the GABAergic positive autofcedback loop in the HC membrane for $g_{\text {ion }}$ is 0.17 units. For explanation, see Appendix.

17) increases as the $\mathrm{HC}$ is hyperpolarized since the $\mathrm{HC}$ membrane potential is further removed from $E_{\mathrm{Cl}}$. Now the response becomes fast because a small hyperpolarization of the $\mathrm{HC}$ will result in a large change in $\mathrm{Cl}^{-}$conductance leads to a large hyperpolarization of the $\mathrm{HC}$ via the GABAergic positive feeback loop. This will lead, after some time, to an even larger further hyperpolarization.

Finally, the open loop gain will drop again since at very hyperpolarized levels the cxtraccllular GABA concentration will become very low and will hardly change with membrane potential (Eq. 5, Fig. 17) and the resulting $\mathrm{Cl}^{-}$conductance has become very small. This variable open loop gain is the reason for the characteristic shape of the response.

Increasing the gain of the loop around $-25 \mathrm{mV}$ in the model, for instance by lowering $[\mathrm{Na}]_{i}, 1 \mathrm{~mm}$, indeed results immediately in fast responses. With this small change in $[\mathrm{Na}]_{i}$, the time to half maximal response decreases from circa $570 \mathrm{msec}$ to 230 msec (not shown).

\section{Conclusions}

The most surprising result of these simulations is that very slow $\mathrm{HC}$ responses can be generated with a positive feedback loop that consists of components with time constants all much smaller then the $\mathrm{HC}$ response. This behavior is completely due to the very low open loop gain at depolarized levels. One could summarize the above discussion by the statement that the kinetics of the $\mathrm{HC}$ response are controlled by the open loop gain of this GABAergic pathway.

\section{References}

Attwell D, Werblin FS, Wilson M, Wu SM (1983) A sign reversing pathway from rods to double and single cones in the retina of the tiger salamander. J Physiol (Lond) 336:313-333.

Ayoub G, Lam DM-K (1984) The release of g-aminobutyric acid from horizontal cells of goldfish (Carassius auratus) retina. J Physiol (Lond) 355:194-214.

Belgum JH, Copenhagen DR (1988) Synaptic transfer of rod signals to horizontal and bipolar cells in the retina of the toad (Bufo marinus). J Physiol (Lond) 396:225-245.

Blatt MR (1986) Interpretation of steady-state current-voltage curves: consequences and implications of current subtraction in transport studies. J Membr Biol 92:91-110. 
DeVries SH, Schwartz EA (1989) Modulation of an electrical synapse between solitary pairs of catfish horizontal cells by dopamine and second messengers. J Physiol (Lond) 414:351-375.

Djamgoz MBA, Laming PJ (1987) Micro-electrode measurements and functional aspects of chloride activity in cyprinid fish retina: extracellular activity and intracellular activities of L-and C-type horizontal cells. Vision Res 27:1481-1489.

Dong C-J, McReynolds JS (1991) The relationship between light, dopamine release and horizontal cell coupling in the mudpuppy retina. J Physiol (Lond) 440:291-309.

Gilbertson TA, Borges S, Wilson M (1990) Horizontal cells contain two types of inhibitory amino acid receptors. Soc Neurosci Abstr 20: 465.

Hamill OP, Marty A, Neher E, Sakmann B, Sigworth FJ (1981) Improved patch-clamp techniques for high resolution current recording from cells and cell-free membrane patches. Pfluegers Arch 391:85100.

Hamming RW (1962) Numerical methods for scientists and engineers, pp 211-215. New York: McGraw-Hill.

Hare WA, Owen WG (1990) Spatial organization of the bipolar cell's receptive field in the retina of the tiger salamander. J Physiol (Lond) 421:223-245.

Heuschneider G, Schwartz RD (1989) cAMP and forskolin decrease gamma-aminobutyric acid gated chloride flux in rat brain synaptoneurosomes. Proc Natl Acad Sci USA 86:2928-2942.

Johnston GA, Krogsgaard-Larsen P, Stephanson AL, Twitchin B (1976) Inhibition of the uptake of GABA and related amino acids in rat brain slices by optical isomers of nipecotic acid. J Neurochem 26 : 1029-1032.

Kamermans M (1989) The functional organization of the horizontal cell layers in carp retina. $\mathrm{PhD}$ thesis, University of Amsterdam, Rodopi.

Kamermans M, Werblin FS (1991) Horizontal cell kinetics in tiger salamander are controlled by GABA-mediated positive feedback. Invest Ophthalmol Vis Sci 32:1190.

Kamermans M, Van Dijk BW, Spekreijse H, Zweypfenning RCVJ (1989a) Lateral feedback from monophasic horizontal cells to cones in carp retina. I. Experiments. J Gen Physiol 93:68 1-694.

Kamermans M, Van Dijk BW, Spekreijse H (1989b) Lateral feedback from monophasic horizontal cells to cones in carp retina. II. A quantitative model. J Gen Physiol 93:695-714.

Kamermans M, Van Dijk BW, Spekreijse H (1990) An evaluation of dopamine and light induced changes in carp horizontal cells. Invest Ophthalmol Vis Sci 31:117.

Kamermans M, Van Dijk BW, Spekreijse H, Werblin FS (1991) A model for the changes in coupling and kinetics of cone driven retinal horizontal cells during light/dark adaptation. In: Analysis and modeling of neural systems (Beckman FH, ed), pp 223-230. Boston: Kluwer Academic.

Kaneko A (1971) Electrical connections between horizontal cells in the dogfish retina. J Physiol (Lond) 213:95-105.

Kanner BI, Schuldiner S (1987) Mechanism of Iransport and storage of neurotransmitters. CRC Crit Rev 22:1-38.

Keynan S, Kanner BI (1988) $\gamma$-Aminobutyric acid transport in reconstituted preparations from rat brain: coupled sodium and chloride fluxes. Biochemistry 27:12-17.

Knapp AG, Dowling JE (1987) Dopamine enhances excitatory amino acid-gated conductances in cultured retinal horizontal cells. Nature $325: 437-439$.

Krogsgraad-I arsen P (1980) Inhibitors of the GABA uptake system. Mol Cell Biochem 31:105-121.

Lam DMK (1972) The biosynthesis and content of gamma-aminobutyric acid in the goldfish retina. $J$ Cell Biol 54:225-231.

Lasater EM (1986) Ionic currents of cultured horizontal cells isolated from white perch retina. J Neurophysiol 55:499-513.

Lasater EM, Dowling JE (1985) Dopamine decreases conductance of the electrical junction between cultured retinal horizontal cells. Proc Natl Acad Sci USA 82:3025-3029.
Malchow RP, Ripps H (1990) Effects of $\gamma$-aminobutyric acid on skate retinal horizontal cells: evidence for an electrogenic uptake mechanism. Proc Natl Acad Sci USA 87:8945-8949.

Mangel SC, Dowling JE (1985) Responsiveness and receptive field size of carp horizontal cells are reduced by prolonged darkness and dopamine. Science 229:1 107-1109.

Marshall LM, Werblin FS (1978) Synaptic transmission to the horizontal cells in the retina of larval tiger salamander. J Physiol (Lond) 279:321-346.

Miller RF, Dacheux RF (1983) Intracellular chloride in retinal neurons: measurement and meaning. Vision Res 23:399-411.

Miyachi E-I, Murakami M (1989) Decoupling of horizontal cells in carp and turtle retinae by intracellular injection of cyclic AMP. J Physiol (Lond) 419:213-224.

O'Brien DR, Dowling JE (1985) Dopaminergic regulation of GABA release from the intact goldfish retina. Brain Res 360:41-50.

Schultz SC (1986) Ion-coupled transport of organic solutes across biological membranes. In: Physiology of membrane disorders, $2 \mathrm{~d}$ ed (Andreoti TH, Hoffman JF, Fanestil DD, Schultz SG, eds), pp 293294. New York: Plenum.

Schwartz EA (1982) Calcium independent release of GABA from isolated horizontal cells of the toad retina. J Physiol (Lond) 323:211227.

Schwartz EA (1987) Depolarization without calcium can release $\gamma$-aminobutyric acid from a retinal neuron. Science 238:350-355.

Stockton RA, Slaughter MM (1991) Depolarizing actions of GABA and glycine on amphibian retinal horizontal cells. J Neurophysiol 65: $680-692$.

Stone S, Witkovsky P (1984) The actions of $\gamma$-aminobutyric acid, glycine and their antagonists upon horizontal cells of the Xenopus retina. J Physiol (Lond) 353:249-264.

Thibos LN, Werblin FS (1978a) The response properties of the steady antagonistic surround in the mudpuppy retina. J Physiol (Lond) 278: $79-99$.

Thibos LN, Werblin FS (1978b) The properties of surround antagonism elicited by spinning windmill patterns in the mudpuppy retina. J Physiol (Lond) 278:101-116.

Werblin FS (1978) Transmission along and between rods in the tiger salamander retina. J Physiol (Lond) 280:449-470.

Witkovsky P, Stone S (1987) GABA and glycine modify the balance of rod and cone inputs to horizontal cells in the Xenopus retina. Exp Biol 47:13-22.

Wu SM (1987) Light dependent synaptic delay between photoreceptors and horizontal cells in the tiger salamander retina. Vision Res 27: $520-523$.

Wu SM (1988) The OFF-overshoot responses of photoreceptors and horizontal cells in the light adapted retinas of tiger salamander. Exp Eye Res 47:261-268.

Wu SM, Yang X-L (1988) Electrical coupling between rods and concs in the tiger salamander retina. Proc Natl Acad Sci USA 85:275-278.

Yang X-L, Wu SM (1989a) Effects of background illumination on horizontal cell responses in the tiger salamander retina. J Neurosci 9:815-826.

Yang X-L, Wu SM (1989b) Effects of prolonged light exposure, GABA and glycine on horizontal cell responses in tiger salamander retina. $J$ Neurophysiol 61:1025-1035.

Yang X-L, Wu SM (1989c) Effects of CNQX, APB, PDA and kynurenate on horizontal cells of the tiger salamander retina. Vis Neurosci 3 : 207-212.

Yazulla $S$ (1985) Evoked efflux of $\left[{ }^{3} \mathrm{H}\right] \mathrm{GABA}$ from goldfish retina in the dark. Brain Res 325:171-180.

Yazulla S, Kleinschmidt J (1982) Dopamine blocks carrier mediated relcase of GABA from retinal horizontal cclls. Brain Res 233:211215.

Yazulla S, Kleinschmidt J (1983) Carrier mediated release of GABA from retinal horizontal cells. Brain Res 263:63-75. 